\title{
Nutrient demand interacts with grass maturity to affect milk fat concentration and digestion responses in dairy cows
}

\author{
K. L. Kammes and M. S. Allen ${ }^{1}$ \\ Department of Animal Science, Michigan State University, East Lansing 48824-1225
}

\begin{abstract}
Effects of grass maturity on dry matter intake (DMI), milk production, ruminal fermentation and pool sizes, digestion and passage kinetics, and chewing activity and the relationship of these effects with preliminary DMI (pDMI) were evaluated using 13 ruminally and duodenally cannulated Holstein cows in a crossover design with a 14-d preliminary period and two 18-d treatment periods. During the preliminary period, pDMI of individual cows ranged from 23.5 to $28.2 \mathrm{~kg} / \mathrm{d}$ (mean $=26.1 \mathrm{~kg} / \mathrm{d})$ and $3.5 \%$ fat-corrected milk $(\mathrm{FCM})$ yield ranged from 30.8 to $57.2 \mathrm{~kg} / \mathrm{d}($ mean $=43.7 \mathrm{~kg} / \mathrm{d})$. Experimental treatments were diets containing orchardgrass silage harvested either (1) early-cut, less mature (EC) or (2) late-cut, more mature (LC) as the sole forage. Early- and late-cut orchardgrass contained 44.9 and $54.4 \%$ neutral detergent fiber (NDF) and 20.1 and $15.3 \%$ crude protein, respectively. Forage:concentrate ratio was 58:42 and 46:54 for EC and LC, respectively; both diets contained approximately $25 \%$ forage NDF and $30 \%$ total NDF. Preliminary DMI, an index of nutrient demand, was determined during the last $4 \mathrm{~d}$ of the preliminary period when cows were fed a common diet and used as a covariate. Main effects of grass maturity and their interaction with pDMI were tested by ANOVA. The EC diet decreased milk yield and increased milk fat concentration compared with the LC diet. Grass maturity and its interaction with pDMI did not affect $\mathrm{FCM}$ yield, DMI, rumen $\mathrm{pH}$, or microbial efficiency. The EC diet increased rates of ruminal digestion of potentially digestible NDF and passage of indigestible NDF (iNDF) compared with the LC diet. The lower concentration and faster passage rate of iNDF for EC resulted in lower rumen pools of iNDF, total NDF, organic matter, and dry matter for EC than LC. Ruminal passage rates of potentially digestible NDF and starch were related to level of intake (quadratic and linear interactions, respectively) and subsequently
\end{abstract}

Received September 21, 2011.

Accepted May 17, 2012.

${ }^{1}$ Corresponding author: allenm@msu.edu affected ruminal digestibility of these nutrients. The EC diet decreased eating, ruminating, and total chewing time per unit of forage NDF intake compared with the LC diet. When grass silage was the only source of forage in the diet, cows supplemented with additional concentrate to account for decreasing protein and increasing fiber concentrations associated with more mature grass had similar feed intake and produced similar FCM yields as cows fed less mature grass.

Key words: grass maturity, digestion kinetics, chewing activity, milk fat

\section{INTRODUCTION}

Forage maturity at harvest affects the supply and utilization of nutrients in dairy cows fed forage-based diets. Maturity affects the yield and quality of forages, and time of harvest is a compromise between these factors. As plants grow and mature, total yield of DM increases but nutritive quality generally decreases because of increasing fiber concentration and lignification of fiber and decreasing protein concentration. Therefore, producing high-quality forage is largely dependent on harvesting at the optimum maturity. Although dairy cows can be fed supplemental concentrate to improve milk production when they are fed low-quality forage, feeding quality forages can optimize milk production, improve cow health, reduce purchased feed costs, and increase dairy profitability.

Increasing maturity in perennial forages reduces digestibility and intake potential of forages due to increased concentration of NDF and greater lignification of the NDF. This not only decreases the potentially digestible NDF (pdNDF) concentration but also decreases the digestion rate of the remaining pdNDF (Smith et al., 1972), which might allow particulate matter to remain buoyant longer, decreasing specific gravity and rate of passage from the rumen (Jung and Allen, 1995). This suggests that more mature forages will result in slower passage rates from the rumen and greater ruminal distention. However, rate of particle size reduction by chewing is greater for more mature grass (Poppi et al., 1981; Ulyatt, 1983) because of greater fragility. This more rapid particle size reduction 
Table 1. Characterization of 13 cows during the final $4 \mathrm{~d}$ of the 14-d preliminary period, when cows were fed a common diet

\begin{tabular}{lccccc}
\hline Parameter & Median & Mean & SD & Minimum & Maximum \\
\hline Parity $_{\text {BW, }}^{1} \mathrm{~kg}$ & 3 & 2.77 & 1.07 & 2 & 6 \\
BCS & 598 & 588 & 55 & 498 & 665 \\
DIM & 2.42 & 2.48 & 0.68 & 1.50 & 4.00 \\
Milk, kg/d & 126 & 164 & 85 & 73 & 329 \\
$3.5 \% \mathrm{FCM}, \mathrm{kg} / \mathrm{d}$ & 43.2 & 43.2 & 7.7 & 29.1 & 55.7 \\
DMI, kg/d & 44.9 & 43.7 & 7.7 & 30.8 & 57.2 \\
\hline
\end{tabular}

${ }^{1}$ Empty BW (ruminal digesta removed).

could increase passage rate for more mature forages, acting in opposition to the expected effects of buoyancy. Orchardgrass (OG; Dactylis glomerata L.) was selected as a representative cool-season grass for use in this experiment.

In addition to the combination of dietary factors affecting ruminal distention and rate of particle breakdown, the individual cow's appetite will also affect the responses of passage rate and intake to forage maturity. Cows respond differently to treatments depending on their level of intake (Voelker Linton and Allen, 2008) and production (Oba and Allen, 1999). Because grass maturity and level of intake affect ruminal passage and digestion rates and, thus, digesta fill in the rumen, the response to effects of grass maturity and its relationship with intake level should be assessed to determine if responses to treatment vary among cows with a wide range in DMI. We hypothesized that responses of DMI to grass maturity are related to level of intake and less mature grass will permit a greater increase in DMI than more mature grass as feed intake increases.

The objectives of this experiment were to evaluate the relationships between level of intake and effects of grass maturity on DMI, milk production, ruminal fermentation and pool sizes, digestion and passage kinetics, and chewing behavior in lactating dairy cows. This study allowed effects of the interaction between grass maturity and preliminary DMI (pDMI) to be evaluated. The use of pDMI, an index of nutrient demand, allowed the evaluation of treatments on animal responses in relation to level of intake and provided an indicator to test effects of intake level independent of treatments.

\section{MATERIALS AND METHODS}

\section{Cows and Treatments}

Experimental procedures were approved by the Institutional Animal Care and Use Committee at Michigan State University (East Lansing). Thirteen multiparous Holstein cows from the Michigan State University Dairy
Cattle Teaching and Research Center were assigned randomly to treatment sequence in a crossover design experiment with one 14-d preliminary period and two 18-d experimental periods. The first $10 \mathrm{~d}$ of each period were allowed for diet adaptation and samples were collected during the final $4 \mathrm{~d}$ of the preliminary period and $8 \mathrm{~d}$ of each experimental period. Cows were 164 \pm 85 (mean \pm SD) DIM at the end of the preliminary period and were selected to provide a wide range and uniform distribution of pDMI and milk yield. During the final $4 \mathrm{~d}$ of the $14-\mathrm{d}$ preliminary period, the average pDMI among cows ranged from 23.5 to $28.2 \mathrm{~kg} / \mathrm{d}$ (mean $=26.1 \mathrm{~kg} / \mathrm{d}$ ) and $3.5 \% \mathrm{FCM}$ yield ranged from 30.8 to $57.2 \mathrm{~kg} / \mathrm{d}($ mean $=43.7 \mathrm{~kg} / \mathrm{d}$; Table 1$)$. Prior to calving, cows were cannulated ruminally (Bar Diamond Inc., Parma, ID) and duodenally with a gutter-type $\mathrm{T}$ cannula placed approximately $10 \mathrm{~cm}$ distal to the pylorus (Joy et al., 1997). Surgery was performed at the Department of Large Animal Clinical Science, College of Veterinary Medicine, Michigan State University.

Experimental treatments were diets containing OG silage from one field harvested either (1) early-cut, less mature (EC) or (2) late-cut, more mature (LC) as the sole forage. Orchardgrass (Baridana cultivar; Barenbrug USA, Tangent, OR) was produced at the campus farm at Michigan State University, chopped to 10-mm theoretical length of cut, and ensiled in AgBags (Ag-Bag Systems Inc., St. Nazianz, WI). During the sample collection periods, early- and late-cut OG contained 44.9 and $54.4 \% \mathrm{NDF}$ and 20.1 and $15.3 \%$ $\mathrm{CP}$, respectively (DM basis; Table 2). Diets EC and LC were formulated to contain $25 \%$ forage NDF, $30 \%$ total NDF, and $18 \% \mathrm{CP}$. We acknowledge that these treatments affect dietary starch concentration, but maintaining similar forage and total NDF concentrations for both treatments was of primary interest. The diet fed during the preliminary period was formulated so that early- and late-cut OG each contributed $50 \%$ of forage NDF. Diets also contained dry ground corn, soybean meal ( $48 \%$ CP), SoyPLUS (West Central Soy Cooperative, Ralston, IA), vitamin-mineral premix, and limestone (Table 3). 
Table 2. Chemical composition, particle size distribution, and fermentation parameters of the early-cut or late-cut orchardgrass silage included in the treatment diets

\begin{tabular}{|c|c|c|}
\hline \multirow[b]{2}{*}{ Item } & \multicolumn{2}{|c|}{ Orchardgrass silage } \\
\hline & Early & Late \\
\hline \multicolumn{3}{|l|}{ Chemical composition } \\
\hline DM, \% & 37.3 & 31.9 \\
\hline $\mathrm{OM}, \%$ of $\mathrm{DM}$ & 90.7 & 92.2 \\
\hline $\mathrm{NDF}, \%$ of $\mathrm{DM}$ & 44.9 & 54.4 \\
\hline iNDF, $1 \%$ of DM & 10.8 & 14.5 \\
\hline iNDF, $\%$ of NDF & 24.1 & 26.6 \\
\hline $\mathrm{ADF}, \%$ of $\mathrm{DM}$ & 28.3 & 33.5 \\
\hline $\mathrm{ADL}, \%$ of DM & 4.08 & 4.67 \\
\hline $\mathrm{CP}, \%$ of DM & 20.1 & 15.3 \\
\hline Starch, \% of DM & 2.92 & 2.10 \\
\hline IV NDF digestibility, ${ }^{2} \%$ & 69.4 & 57.3 \\
\hline \multicolumn{3}{|l|}{ Particle size distribution ${ }^{3}$} \\
\hline \multicolumn{3}{|l|}{ Wet sieving, \% DM retained } \\
\hline $19.0 \mathrm{~mm}$ & 18.1 & 20.6 \\
\hline $9.50 \mathrm{~mm}$ & 22.9 & 24.3 \\
\hline $4.75 \mathrm{~mm}$ & 32.9 & 24.6 \\
\hline $2.36 \mathrm{~mm}$ & 18.7 & 21.5 \\
\hline $1.18 \mathrm{~mm}$ & 3.98 & 5.17 \\
\hline $0.600 \mathrm{~mm}$ & 1.59 & 2.00 \\
\hline$<0.300 \mathrm{~mm}$ & 1.94 & 1.83 \\
\hline Mean particle size ${ }^{4} \mathrm{~mm}$ & 11.4 & 12.0 \\
\hline \multicolumn{3}{|l|}{ Penn State Particle } \\
\hline \multicolumn{3}{|l|}{ Separator, \% DM retained } \\
\hline$>19.0 \mathrm{~mm}$ & 37.8 & 39.7 \\
\hline 19.0 to $8.0 \mathrm{~mm}$ & 38.5 & 37.6 \\
\hline$<8.0 \mathrm{~mm}$ & 23.7 & 22.7 \\
\hline \multicolumn{3}{|l|}{ Fermentation } \\
\hline $\mathrm{pH}$ & 4.90 & 4.57 \\
\hline Acetic acid, $\%$ of DM & 1.37 & 2.10 \\
\hline Propionic acid, $\%$ of DM & 0.38 & 0.24 \\
\hline Butyric acid, $\%$ of DM & $<0.01$ & $<0.01$ \\
\hline Lactic acid, $\%$ of DM & 5.93 & 6.30 \\
\hline Ethanol, \% of DM & 0.20 & 0.11 \\
\hline Ammonia, $\mathrm{m} M$ & 4.31 & 3.12 \\
\hline
\end{tabular}

${ }^{1} \mathrm{iNDF}=$ indigestible NDF.

${ }^{2}$ Thirty-hour in vitro NDF digestibility.

${ }^{3}$ Particle size distributions of silages were measured each period $(\mathrm{n}=$ 2).

${ }^{4}$ Mean particle size calculated from particle size distribution determined by wet sieving.

\section{Data and Sample Collection}

Throughout the experiment, cows were housed in tie-stalls and fed diets as TMR once daily $(1130 \mathrm{~h})$ at $110 \%$ of expected intake. The amount of feed offered and refused (orts) was weighed daily for each cow. Forage samples were collected twice weekly and analyzed to adjust diets to account for DM, NDF, and CP fluctuation. Samples of all dietary ingredients $(0.5 \mathrm{~kg})$ and orts $(12.5 \%)$ were collected daily from d 11 to 14 during the preliminary period and d 11 to 15 during each experimental period. Samples were frozen immediately after collection at $-20^{\circ} \mathrm{C}$ and combined to 1 composite sample per period before analysis.
Cows were moved to an exercise lot twice daily $(0230$ and $1300 \mathrm{~h}$ ) before milking in a parlor (0400 and 1430 h). Milk yield was measured and milk was sampled at each milking on d 11 to 14 of the preliminary period and on d 11 to 15 of the experimental periods. Rumenempty BW was measured by weighing the cow after evacuation of ruminal digesta on d 14 of the preliminary period and d 18 of each experimental period. Body condition score was determined on the same days by 3 trained investigators blinded to treatments (Wildman et al., 1982; 5 -point scale where $1=$ thin and $5=$ fat). Chewing activity was monitored and recorded by observation every 5 min for $24 \mathrm{~h}$ on d 16 of each experimental period. Activity was noted as eating, ruminating, drinking, or idle for each cow at each time.

Duodenal samples (900 mL), fecal samples (500 g), rumen fluid, and particulate samples for microbial isolation (400 g), and rumen fluid samples for $\mathrm{pH}$, concentrations of VFA, lactate, and ammonia $(100 \mathrm{~mL})$ were collected every $15 \mathrm{~h}$ from d 11 to 15 of each experimental period so that 8 samples were taken for each cow in each period, representing every $3 \mathrm{~h}$ of a 24 -h period to account for diurnal variation. Rumen fluid and particulate matter for microbial isolation were collected from the reticulum, near the reticular-omasal orifice, transported to the laboratory, and processed. Rumen fluid for $\mathrm{pH}$, VFA, lactate, and ammonia were obtained

Table 3. Ingredients and chemical composition of preliminary and treatment diets (as analyzed) containing either early-cut or late-cut orchardgrass silage as the sole source of forage

\begin{tabular}{lccc}
\hline Composition & Preliminary & Early & Late \\
\hline Ingredient, \% DM & & & \\
Orchardgrass silage, early cut & 27.5 & 58.1 & - \\
Orchardgrass silage, late cut & 23.1 & - & 45.9 \\
Dry ground corn & 33.3 & 31.0 & 35.2 \\
Soybean meal (48\% CP) & 7.49 & 2.39 & 10.3 \\
SoyPLUS & 3.39 & 3.39 & 3.39 \\
Vitamin-mineral mix ${ }^{2}$ & 3.99 & 3.99 & 3.99 \\
Limestone & 1.20 & 1.20 & 1.20 \\
Chemical composition & & & \\
DM, \% & 48.7 & 49.6 & 49.2 \\
OM, \% of DM & 91.5 & 90.9 & 92.0 \\
NDF, \% of DM & 29.6 & 30.5 & 30.5 \\
\% of forage NDF & 25.3 & 26.1 & 25.0 \\
\% of NDF from forage & 85.5 & 85.4 & 81.9 \\
iNDF, \% of DM & NA & 7.98 & 8.87 \\
iNDF, \% of NDF & NA & 26.2 & 29.1 \\
CP, \% of DM & 18.6 & 18.1 & 18.2 \\
Starch, \% of DM & 26.9 & 25.1 & 27.7 \\
\hline
\end{tabular}

${ }^{1}$ West Central Soy Cooperative, Ralston, IA.

${ }^{2}$ Vitamin-mineral mix contained (DM basis) $16.5 \%$ sodium bicarbonate, $14.2 \%$ magnesium sulfate, $7.1 \%$ salt, $5.8 \%$ dicalcium phosphate, $2.4 \%$ trace mineral premix, $0.4 \%$ vitamin $\mathrm{A}, 0.4 \%$ vitamin $\mathrm{D}, 0.2 \%$ vitamin $\mathrm{E}$, and $53.1 \%$ dry ground corn as a carrier.

${ }^{3} \mathrm{iNDF}=$ indigestible NDF.

${ }^{4} \mathrm{NA}=$ no analysis for preliminary diet. 
by combining digesta from 5 different sites in the rumen and straining it through nylon mesh $(\sim 1-\mathrm{mm}$ pore size); fluid $\mathrm{pH}$ was recorded immediately. Samples were stored at $-20^{\circ} \mathrm{C}$.

Ruminal contents were evacuated manually through the ruminal cannula $4 \mathrm{~h}$ after feeding at the beginning of $\mathrm{d} 17(1530 \mathrm{~h})$, and $42 \mathrm{~h}$ later, $2 \mathrm{~h}$ before feeding at the end of d $18(0930 \mathrm{~h})$ for each experimental period. Total rumen content mass and volume were determined. To ensure accurate sampling, every tenth handful of digesta (10\%) was separated for a subsample throughout evacuation. This subsample was squeezed into primarily solid and liquid phases. Both phases were weighed and sampled $(350 \mathrm{~mL})$ for determination of nutrient pool size. All samples were stored at $-20^{\circ} \mathrm{C}$.

\section{Sample Analysis and Calculations}

Milk yield recorded at both milkings were summed for a daily total, which were averaged for each collection period. Milk samples were analyzed for fat, true protein, lactose, SNF, and MUN with infrared spectroscopy by Michigan DHIA (East Lansing). Yields of $3.5 \%$ FCM and milk components were calculated using milk yield and component concentrations for each milking, summed for a daily total, and averaged for each collection period. Milk samples used for analysis of FA profile were composited based on milk fat yield and centrifuged at $17,800 \times g$ for $30 \mathrm{~min}$ at $8^{\circ} \mathrm{C}$. Fat cake (300 to $400 \mathrm{mg}$ ) was extracted according to Hara and Radin (1978), and methyl esters were formed according to Christie (1982) as modified by Chouinard et al. (1999). Fatty acids were quantified by gas chromatography (model 8500; Perkin-Elmer Corp., Norwalk, CT) according to Kramer et al. (1997) using a SP-2560 capillary column $(100 \mathrm{~m} \times 0.20 \mathrm{~mm}$ i.d. with $0.02-\mu \mathrm{m}$ film thickness; Supelco Inc., Bellefonte, PA). The oven temperature was $70^{\circ} \mathrm{C}$ for $4 \mathrm{~min}$ and then increased $13^{\circ} \mathrm{C} / \mathrm{min}$ to $175^{\circ} \mathrm{C}$ and held for $27 \mathrm{~min}$ before being increased again at $4^{\circ} \mathrm{C} / \mathrm{min}$ to $215^{\circ} \mathrm{C}$ and held for 31 min. Helium flow was $20 \mathrm{~cm} / \mathrm{s}$, and the total run time was $80 \mathrm{~min}$.

Forage samples were combined to 1 composite sample per forage per period. Particle size distribution was determined using the Penn State Particle Separator containing 2 sieves (19 and $8 \mathrm{~mm}$ ) and a pan (Lammers et al., 1996). In addition, samples were wet sieved manually and sequentially through screens with the following aperture sizes: 19.0, 9.50, 4.75, 2.36, 1.18, 0.600, $0.300,0.150,0.075$, and $0.038 \mathrm{~mm}$. The fraction of DM retained on the screens from wet sieving was used to calculate mean particle size.
Diet ingredients, orts, and feces were lyophilized (Tri-Philizer MP; FTS Systems Inc., Stone Ridge, NY). All dried samples were ground with a Wiley mill (1-mm screen; Arthur H. Thomas Co., Philadelphia, PA). Dried, ground fecal samples were combined on an equal DM basis into 1 sample per cow per period. Frozen duodenal samples for each cow period $(n=8)$ were chopped finely using a commercial food processor (84142 Food cutter; Hobart Manufacturing Co., Troy, $\mathrm{OH})$ and subsampled in the frozen state to obtain representative samples. These duodenal subsamples and the $350 \mathrm{~mL}$ of ruminal solid and liquid samples were lyophilized and ground as described above. Dried ruminal solid and liquid samples were recombined according to the original ratio of solid and liquid DM.

Samples were analyzed for ash, NDF, indigestible NDF (iNDF), ADF, acid detergent sulfuric acid lignin (ADL), CP, and starch. Ash concentration was determined after $5 \mathrm{~h}$ combustion at $500^{\circ} \mathrm{C}$ in a muffle furnace. Concentrations of NDF were determined according to Mertens (2002) and ADF and ADL according to Goering and Van Soest (1970) with the omission of decalin as an antifoam agent and asbestos as a filtering aid. Indigestible NDF was estimated as NDF residue after 240-h in vitro fermentation (Goering and Van Soest, 1970); flasks were reinoculated at $120 \mathrm{~h}$ to ensure a viable microbial population. Forage NDF digestibility was determined by 30 -h in vitro fermentation (Goering and Van Soest, 1970). Ruminal fluid for the in vitro incubations was collected from a nonpregnant dry cow fed dry hay only. The fraction of pdNDF was calculated by difference $(1.00$ - iNDF). Crude protein was analyzed according to Hach et al. (1987). Starch was measured by an enzymatic method (Karkalas, 1985) after samples were gelatinized with sodium hydroxide. Glucose concentration was measured using a glucose oxidase method (Glucose kit \#510; Sigma Chemical Co., St. Louis, MO), and absorbance was determined with a micro-plate reader (SpectraMax 190; Molecular Devices Corp., Sunnyvale, CA). Concentrations of all nutrients except DM were expressed as percentages of $\mathrm{DM}$ determined by drying at $105^{\circ} \mathrm{C}$ in a forced-air oven for more than $8 \mathrm{~h}$.

Duodenal digesta were analyzed for purines and ammonia to estimate microbial $\mathrm{N}$ (MN) flow and nonammonia, nonmicrobial N (NANMN) flow to the duodenum. Purine concentration was used as a microbial marker, and purine-to-MN ratio was estimated by analysis of microbial pellets obtained by differential centrifugation of the rumen fluid and particulate samples collected near the reticulum. Rumen fluid and particulate matter was blended, strained through nylon mesh, and the liquid portion was centrifuged at $500 \times g$ 
for $15 \mathrm{~min}$. The supernatant was centrifuged at 18,000 $\times g$ for $15 \mathrm{~min}$, and the pellet was washed with $0.9 \%$ $\mathrm{NaCl}$ solution and centrifuged again at $18,000 \times g$ for 15 min, resuspended in water, and lyophilized. Total purines were measured by spectrophotometer (Beckman Instruments Inc., Fullerton, CA) at $260 \mathrm{~nm}$ according to Zinn and Owens (1986). Ammonia concentration was determined for centrifuged duodenal and rumen fluid samples according to Broderick and Kang (1980). Rumen fluid was also analyzed for concentrations of major VFA and lactate by HPLC (Waters Corp., Milford, MA) according to Oba and Allen (2003a).

Dry matter and nutrient intakes were calculated using the composition of feed offered and refused. Ruminal pool sizes (kg) of OM, NDF, iNDF, pdNDF, starch, $\mathrm{MN}$, and NANMN were determined by multiplying the concentration of each component in rumen samples by the ruminal digesta DM mass $(\mathrm{kg})$. Duodenal flows $(\mathrm{kg} / \mathrm{d})$ of DM, OM, total NDF, pdNDF, starch, MN, NANMN, and ammonia $\mathrm{N}$ were determined using iNDF as a flow marker; iNDF intake $(\mathrm{kg} / \mathrm{d})$ was multiplied by the ratio between the component and iNDF in duodenal digesta. Duodenal flow of microbial OM was determined using the purines-to-OM ratio (Oba and Allen, 2003b), and true ruminally digested OM was calculated by subtracting duodenal flow of nonmicrobial OM from OM intake. Indigestible NDF was used as an internal marker to estimate nutrient digestibility in the rumen and in the total tract (Cochran et al., 1986). Turnover rate in the rumen, passage rate from the rumen, and ruminal digestion rate of each component was calculated using the following equations:

$$
\begin{gathered}
\text { Turnover rate }(\% / \mathrm{h})=100 \times(\text { intake of component/ } \\
\text { ruminal pool of component }) / 24 ;
\end{gathered}
$$

Passage rate $(\% / \mathrm{h})=100 \times($ duodenal flow

of component/ruminal pool of component)/24;

Digestion rate $(\% / \mathrm{h})=$ turnover rate in the rumen

$$
(\% / \mathrm{h}) \text { - passage rate from the rumen }(\% / \mathrm{h}) \text {. }
$$

Manually observed chewing activity was summarized by a logic script in Igor Pro (version 6.12; WaveMetrics Inc., Lake Oswego, OR) to generate meal and rumination bout information according to previously established criteria (Dado and Allen, 1994). Variables determined included frequency of meal bouts per day, interval between meals, frequency of ruminating bouts per day, interval between ruminating bouts, eating time per day, ruminating time per day, and total chewing time per day.

\section{Statistical Analysis}

All data were analyzed by using the fit model procedure of JMP (version 8; SAS Institute, Cary, NC). To determine differences between treatments and evaluate interactions of treatment with DMI, where pDMI (calculated as the mean of DMI values on $d 11$ to 14 of the 14-d preliminary period) was used as the covariate for treatment responses, data were analyzed according to the following model: $\mathrm{Y}_{\mathrm{ijk}}=\mu+\mathrm{C}_{\mathrm{i}}+\mathrm{P}_{\mathrm{j}}+$ $\mathrm{T}_{\mathrm{k}}+\mathrm{PT}_{\mathrm{jk}}+\mathrm{pDMI}+\mathrm{T}_{\mathrm{k}} \mathrm{pDMI}+\mathrm{pDMI}^{2}+\mathrm{T}_{\mathrm{k}} \mathrm{pDMI}^{2}$ $+e_{i j k}$, where $Y_{i j k}$ is the dependent variable, $\mu$ is the overall mean, $\mathrm{C}_{\mathrm{i}}$ is the random effect of cow $(\mathrm{i}=1$ to 13), $P_{j}$ is the fixed effect of period ( $\mathrm{j}=1$ to 2$), T_{k}$ is the fixed effect of treatment ( $\mathrm{k}=1$ to 2$), \mathrm{PT}_{\mathrm{jk}}$ is the interaction of period and treatment, pDMI is the linear effect of pDMI, $\mathrm{T}_{\mathrm{k}} \mathrm{pDMI}$ is the interaction of treatment and pDMI (linear), $\mathrm{pDMI}^{2}$ is the quadratic effect of pDMI, $\mathrm{T}_{\mathrm{k}} \mathrm{pDMI}^{2}$ is the interaction of treatment and pDMI (quadratic), and $e_{i j k}$ is the residual error. Least squares means were calculated using mean-centered covariates. Statistical significance for $\mathrm{T}_{\mathrm{k}} \mathrm{pDMI}$ and $\mathrm{T}_{\mathrm{k}} \mathrm{pDMI}^{2}$ indicated that responses to treatment were related to pDMI. Covariate and interaction terms were removed stepwise from the model if $P>0.20$. Treatment effects and their interaction (linear and quadratic relationships) were declared significant at $P \leq 0.05$ and $P \leq 0.10$, respectively. Tendencies for treatment effects and their interactions were declared at $P \leq 0.10$ and $P$ $\leq 0.15$, respectively.

Sixteen cows started the experiment; however, 1 cow was removed from the study due to circumstances unrelated to treatments. Additionally, data from 2 cows were excluded before statistical analysis; one cow had a broken duodenal cannula during the last collection of the second experimental period that was replaced but affected her DMI and, subsequently, rumen empty measurements, and the other cow was considered highly influential based on large Cook's distance values (Cook and Weisberg, 1982) for several response variables of primary interest. Thus, data from 13 cows were statistically analyzed.

\section{RESULTS AND DISCUSSION}

\section{Comparison of Forages and Diets}

Chemical analyses of OG silages are listed in Table 2. As expected, delaying harvest of OG decreased the concentration of CP (20.1 vs. $15.3 \%$ ) and increased concentrations of total NDF (44.9 vs. $54.4 \%$ ) and iNDF (10.8 vs. $14.5 \%$ ). Indigestible NDF, expressed as a percent of NDF, was slightly lower (24.1 vs. $26.6 \%$ of NDF) for early-cut OG than for late-cut OG. In vitro NDF 
Table 4. Milk production and composition, feed intake, and BW change of cows fed treatment diets containing either early-cut or late-cut orchardgrass silage as the sole source of forage

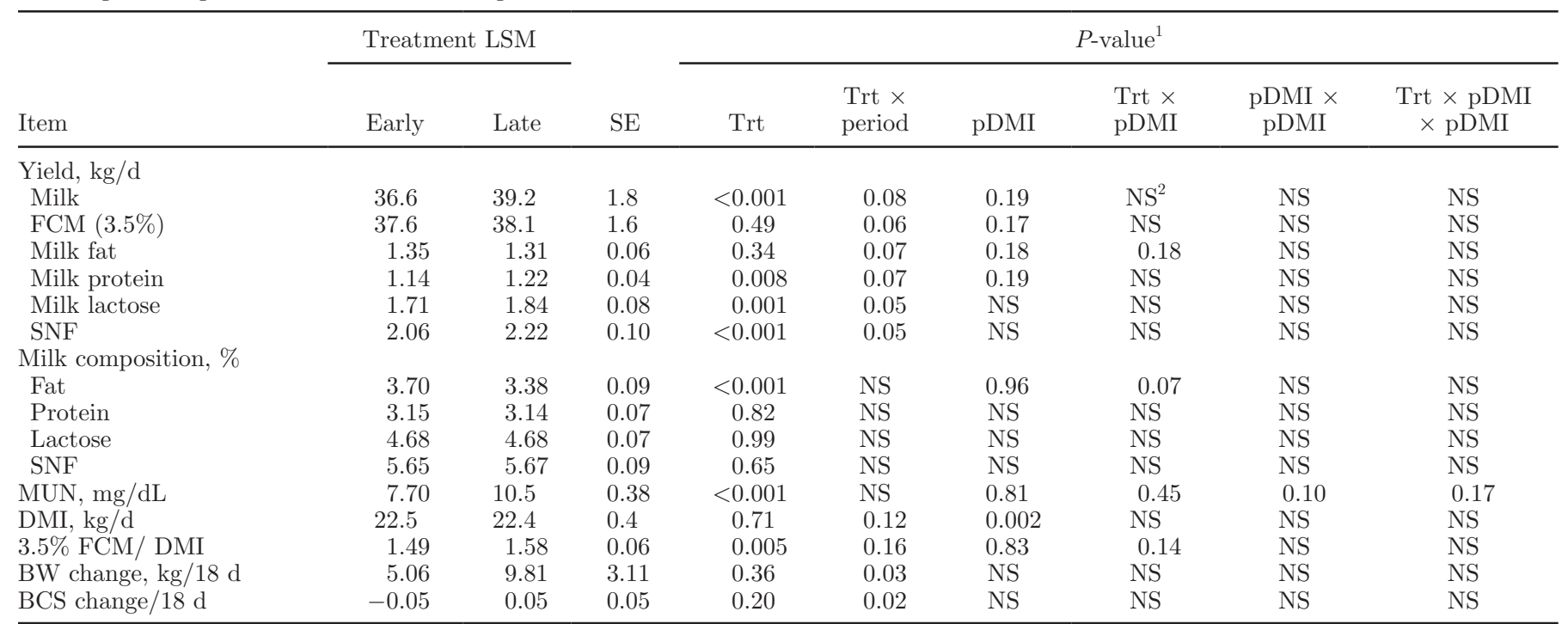

${ }^{1} P$-values for treatment (Trt), Trt by period interaction (Trt $\times$ period), preliminary DMI $(\mathrm{pDMI})$, Trt by pDMI interaction $($ Trt $\times$ pDMI), quadratic effect of pDMI $(\mathrm{pDMI} \times \mathrm{pDMI})$, and Trt by quadratic effect of $\mathrm{pDMI}($ Trt $\times \mathrm{pDMI} \times \mathrm{pDMI})$.

${ }^{2}$ Nonsignificant, with $P>0.20$; term was removed from the statistical model.

digestibility (30-h) was 12.1 percentage units higher for early-cut OG than for late-cut OG (69.4 vs. 57.3\%). Early-cut OG had greater DM concentration, higher $\mathrm{pH}$, and contained less lactic and acetic acids than latecut OG. Physical characteristics (Table 2) of early- and late-cut $O G$ silages were similar for mean particle size and particle size distribution.

Diet ingredients and chemical composition are shown in Table 3. The preliminary diet contained more earlycut OG than late-cut OG, so each forage supplied similar concentrations of forage NDF. Because treatment diets were formulated to contain similar forage NDF concentrations, forage:concentrate ratios were different between diets, with ratios of 58:42 and 46:54 for EC and $\mathrm{LC}$, respectively. Besides forage source, the main differences in diets were the concentrations of corn grain and soybean meal, which were both lower for EC than LC, to account for differences between the grass silages. Both diets had a similar chemical composition, which was mathematically calculated according to the proportion of each feed ingredient in the diet and its respective analytical values, except for starch, which was lower for EC due to more forage and less concentrate in the diet. In both diets, forage NDF provided over $81 \%$ of the total diet NDF.

\section{Effects of Grass Maturity and pDMI}

Results of grass maturity and its interaction with pDMI on milk yield and composition are shown in
Table 4. The EC diet decreased milk yield (36.6 vs. 39.2 $\mathrm{kg} / \mathrm{d}, P<0.001)$ and subsequently yields of protein $(1.14$ vs. $1.22 \mathrm{~kg} / \mathrm{d}, P=0.008)$, lactose (1.71 vs. 1.84 $\mathrm{kg} / \mathrm{d}, P=0.001$ ), and SNF $(2.06$ vs. $2.22 \mathrm{~kg} / \mathrm{d}, P<$ 0.001 ) compared with the LC diet, as concentrations of protein, lactose, and SNF were similar. The EC diet decreased MUN concentration (7.70 vs. $10.5 \mathrm{mg} / \mathrm{dL}$, $P<0.001)$ and increased milk fat concentration (3.70 vs. $3.38 \%, P<0.001)$ compared with the LC diet. The lower milk yield and higher milk fat concentration for EC and higher milk yield and lower milk fat concentration for LC resulted in similar FCM and milk fat yields. The response of milk fat concentration to treatment was related to $\mathrm{pDMI}$ (interaction $P=0.07$; Figure 1) such that EC increased milk fat concentration and LC decreased it as pDMI increased.

The aforementioned results are related to different concentrate levels in the diets, which were necessary to account for changes in chemical composition of grasses with increasing maturity and maintain the same concentration of forage NDF in the diets. The EC diet decreased starch intake $(5.77$ vs. $6.30 \mathrm{~kg} / \mathrm{d}, P<0.001$; Table 5) and ruminal propionate concentration (37.6 vs. $41.5 \mathrm{~m} M, P=0.01$; Table 6 ) compared with the LC diet, which are likely because of lower starch concentration for the EC diet as a result of the ration formulation. Because no difference existed between treatments for acetate concentration, EC increased the acetateto-propionate ratio (2.50 vs. $2.30, P=0.04$; Table 6 ) compared with LC. Additionally, responses of ruminal 


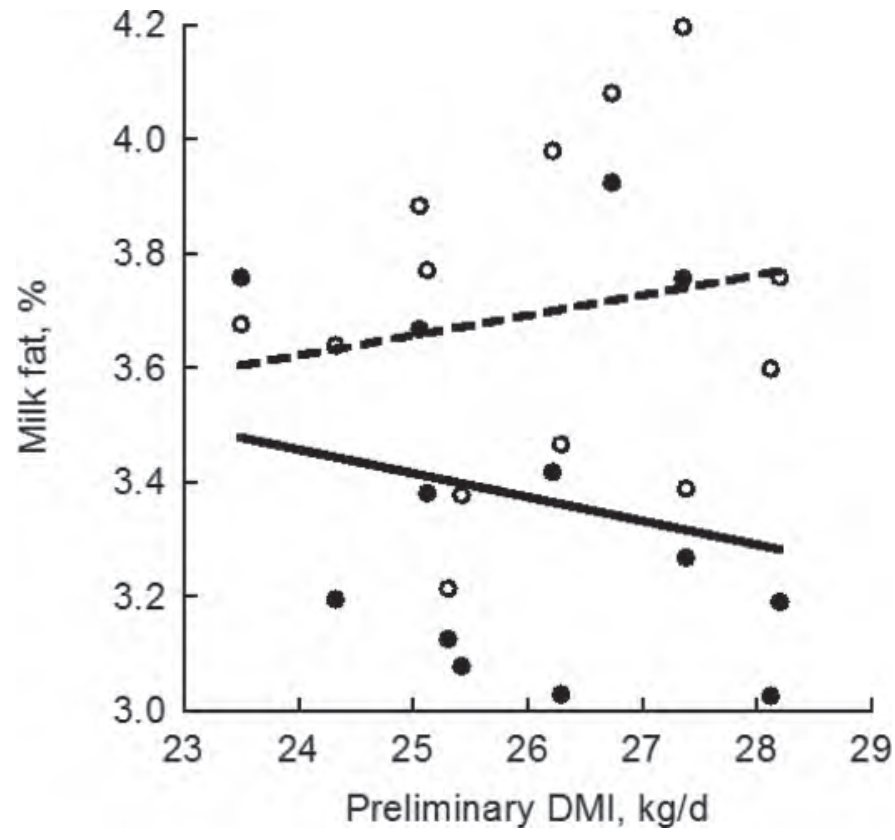

Figure 1. Interaction of early (open circles, dashed line) and late (closed circles, solid line) orchardgrass maturity with preliminary DMI for milk fat concentration $(P=0.07$, linear $)$. Raw data were adjusted for period effects. The preliminary DMI on the x-axis are the mean DMI of individual cows during the final $4 \mathrm{~d}$ of the preliminary period when all cows were fed a common diet. The best-fit lines are drawn to demonstrate the significant interaction even if the individual relationships are not significant.

propionate concentration and acetate-to-propionate ratio tended to be related to $\mathrm{pDMI}$ (interaction $P \leq$ $0.15)$ such that LC increased propionate concentration and decreased acetate-to-propionate ratio as pDMI increased, whereas they remained constant across the range of $\mathrm{pDMI}$ for EC. If propionate concentration in the rumen, which tended to increase for LC as pDMI increased, reflected propionate production, the reduction in milk fat concentration for LC as pDMI increased might be related to propionate production. Greater propionate production could provide precursors for higher milk production and reduce milk fat concentration because of dilution. Based on the milk FA profile (Table 7), the reduction in milk fat concentration observed for LC was not because of diet-induced milk fat depression.

Although $\mathrm{N}$ intake was similar for EC and LC ( $P$ $=0.76$; Table 8), differences in $\mathrm{N}$ sources might have affected $\mathrm{N}$ digestion, as greater quantities of $\mathrm{N}$ were contributed from grass silage for EC and soybean meal for LC (Table 3). Lower MUN concentration for EC is consistent with lower ruminal ammonia concentration $(11.0$ vs. $12.9 \mathrm{mg} / \mathrm{dL}, P=0.001)$ and flow of ammonia $\mathrm{N}$ to the duodenum (14.6 vs. $17.0 \mathrm{~g} / \mathrm{d}, P=0.01)$ for $\mathrm{EC}$ than LC (Table 8). The increased ammonia for LC was not because of ammonia concentration in the silage, which was higher for early-cut $O G$ than late-cut $O G$ (Table 2), nor due to excessive degradation of AA in the rumen, which would result in the production of ammonia and branched-chain VFA, because isovalerate and branched-chain VFA were higher for EC than LC (Table 6). The source of increased ruminal ammonia for LC is not known but might be from greater degradation of protein in soybean meal compared with protein in early-cut OG. The EC diet decreased total-tract N digestion (359 vs. $422 \mathrm{~g} / \mathrm{d}, P=0.002)$ and digestibility (55.7 vs. $64.9 \%, P<0.001)$ compared with the LC diet

Table 5. Starch digestion of cows fed treatment diets containing either early-cut or late-cut orchardgrass silage as the sole source of forage

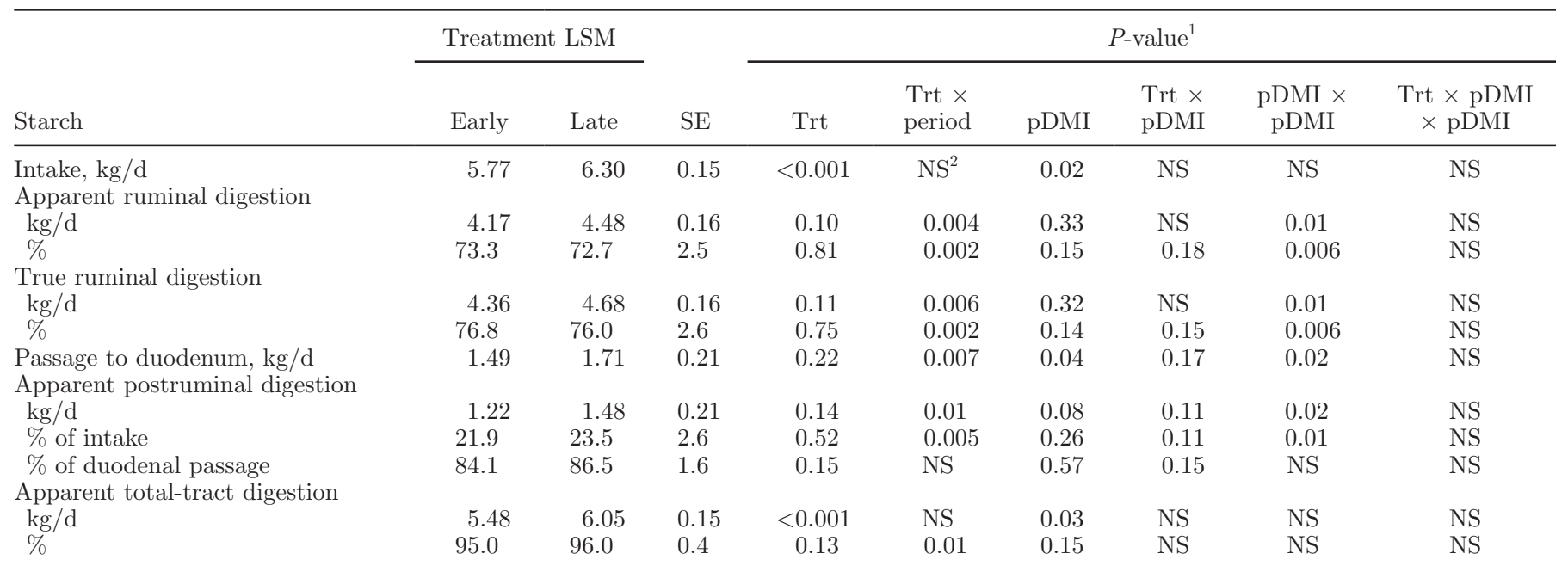

${ }^{1} P$-values for treatment (Trt), Trt by period interaction (Trt $\times$ period), preliminary DMI (pDMI), Trt by pDMI interaction $($ Trt $\times$ pDMI), quadratic effect of $\mathrm{pDMI}(\mathrm{pDMI} \times \mathrm{pDMI})$, and Trt by quadratic effect of $\mathrm{pDMI}($ Trt $\times \mathrm{pDMI} \times \mathrm{pDMI})$.

${ }^{2}$ Nonsignificant, with $P>0.20$; term was removed from the statistical model. 
Table 6. Ruminal VFA concentrations and $\mathrm{pH}$ of cows fed treatment diets containing either early-cut or late-cut orchardgrass silage as the sole source of forage

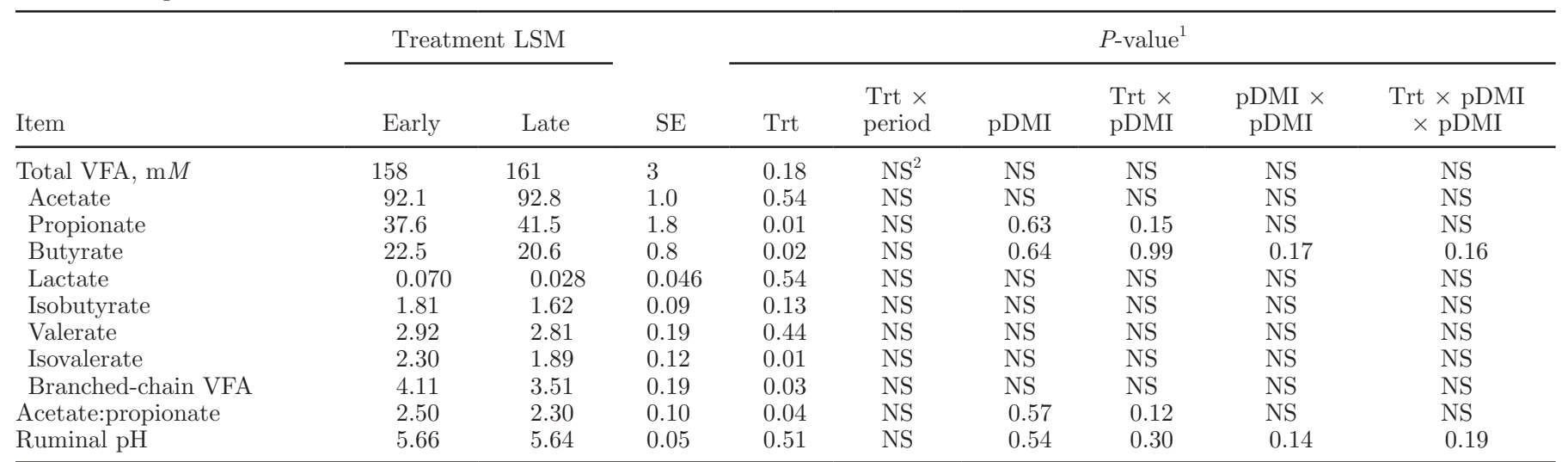

${ }^{1} P$-values for treatment (Trt), Trt by period interaction (Trt $\times$ period), preliminary DMI $(\mathrm{pDMI})$, Trt by pDMI interaction $($ Trt $\times$ pDMI), quadratic effect of $\mathrm{pDMI}(\mathrm{pDMI} \times \mathrm{pDMI})$, and Trt by quadratic effect of $\mathrm{pDMI}($ Trt $\times \mathrm{pDMI} \times \mathrm{pDMI})$.

${ }^{2}$ Nonsignificant, with $P>0.20$; term was removed from the statistical model.

(Table 8), which is likely associated with the differences in $\mathrm{N}$ sources in the diets.

The EC diet increased pdNDF intake (4.98 vs. 4.65 $\mathrm{kg} / \mathrm{d}, P=0.003)$ and decreased iNDF intake (1.79 vs. $1.94 \mathrm{~kg} / \mathrm{d}, P=0.003$ ) compared with the LC diet (Table 9) because of differences in chemical composition of forages due to maturity. However, grass maturity and its interaction with $\mathrm{pDMI}$ did not affect total NDF intake (interaction $P \geq 0.75$, Table 9 ) or DMI (interaction $P$ $\geq 0.84$, Table 10). These results are contrary to our hypothesis that LC would be more filling than EC, causing greater rumen distention and potentially limiting DMI, particularly in cows with high DMI for which ruminal distention is more likely to limit feed intake (Allen, 1996). Oba and Allen (1999) and Voelker et al. (2002) found that DMI responses varied by production level, which is generally correlated with DMI (NRC, 2001), where DMI was increasingly limited by high-fill diets compared with low-fill diets as milk yield increased. Additionally, as DMI became more limited by fill, we expected passage rate of iNDF to increase more for EC than for LC. Although EC increased ruminal passage rate of iNDF compared with LC (2.69 vs. $2.04 \% / \mathrm{h}, P<$ 0.001; Table 11), effect of treatment on passage rate of iNDF was not related to pDMI (interaction $P \geq 0.36$ ).

The lower concentration and faster rate of passage of iNDF for EC are reflected in the lower rumen pool sizes (Table 12) of iNDF (2.76 vs. $4.17 \mathrm{~kg}, P<0.001)$ compared with LC, which also resulted in lower rumen pools of NDF (6.03 vs. $7.30 \mathrm{~kg}, P<0.001)$, OM (10.4 vs. $11.8 \mathrm{~kg}, P<0.001)$, and $\mathrm{DM}(11.4$ vs. $12.8 \mathrm{~kg}, P$ $<0.001)$ for EC than LC. Furthermore, rumen content wet weight tended to be lower for $\mathrm{EC}$ than $\mathrm{LC}(P=$ 0.06; Table 12) and volume increased faster for EC than $\mathrm{LC}$ as $\mathrm{pDMI}$ increased (interaction $P=0.10$; Figure 2) such that cows with high pDMI had similar volumes for EC and LC.

The EC diet increased ruminal digestion rate of pdNDF (5.09 vs. $4.15 \% / \mathrm{h}, P=0.009)$ and decreased ruminal passage rate of pdNDF $(0.65$ vs. $1.28 \% / \mathrm{h}, P$

Table 7. Milk FA profile of cows fed treatment diets containing either early-cut or late-cut orchardgrass silage as the sole source of forage

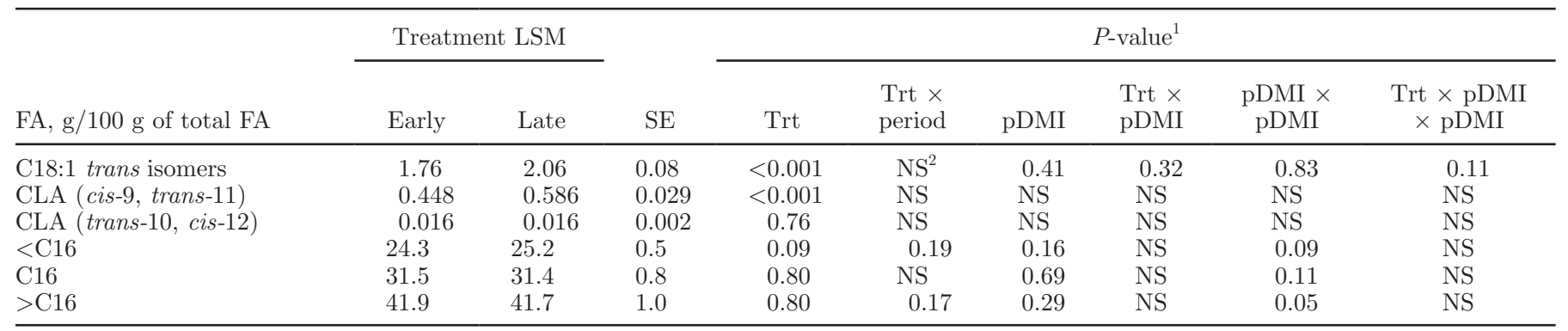

${ }^{1} P$-values for treatment (Trt), Trt by period interaction $($ Trt $\times$ period), preliminary DMI $(\mathrm{pDMI})$, Trt by pDMI interaction $($ Trt $\times$ pDMI), quadratic effect of pDMI $(\mathrm{pDMI} \times \mathrm{pDMI})$, and Trt by quadratic effect of $\mathrm{pDMI}($ Trt $\times \mathrm{pDMI} \times \mathrm{pDMI})$.

${ }^{2}$ Nonsignificant, with $P>0.20$; term was removed from the statistical model. 
Table 8. Nitrogen metabolism of cows fed treatment diets containing either early-cut or late-cut orchardgrass silage as the sole source of forage

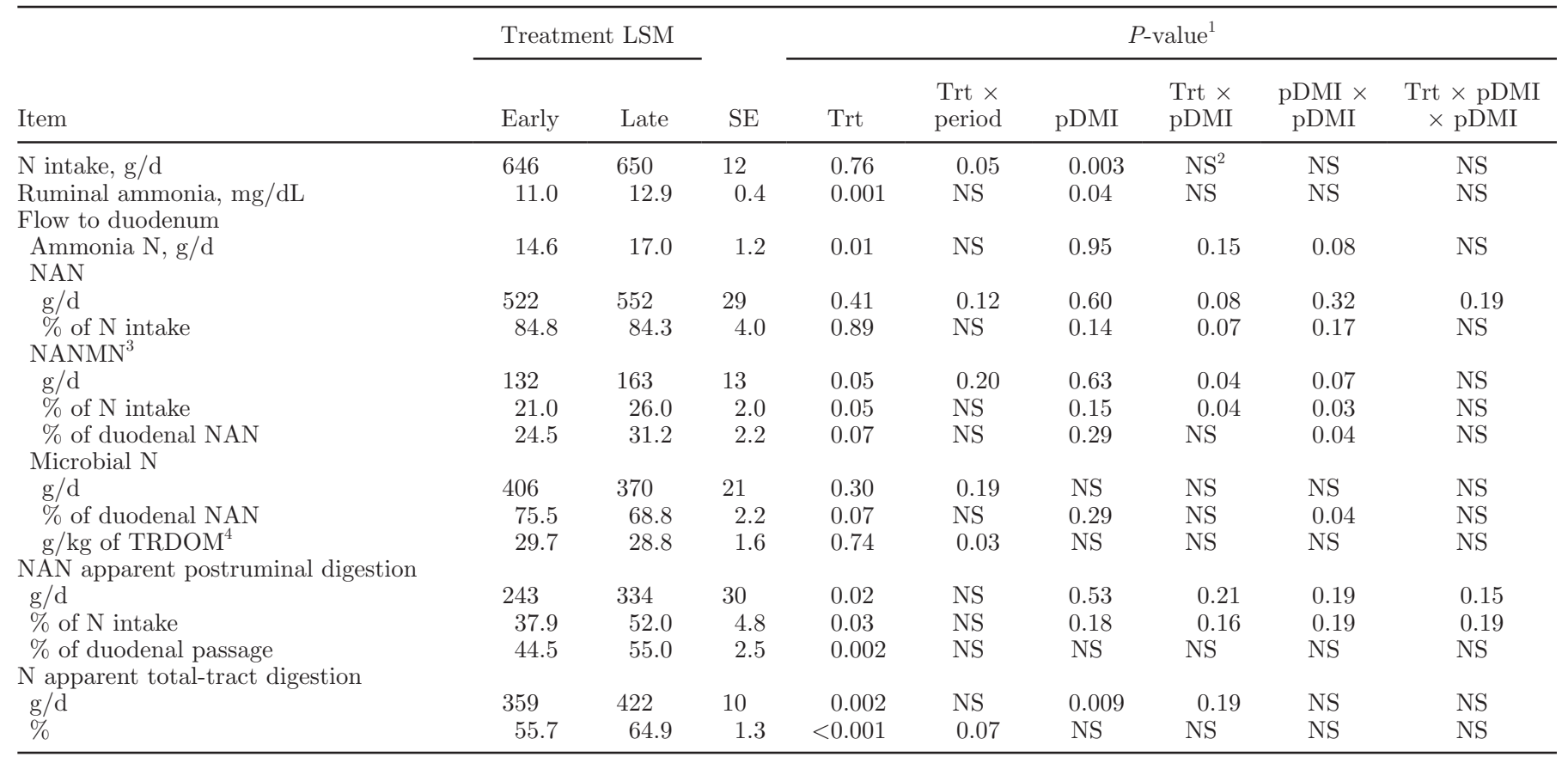

${ }^{1} P$-values for treatment (Trt), Trt by period interaction (Trt $\times$ period), preliminary DMI (pDMI), Trt by pDMI interaction $($ Trt $\times$ pDMI), quadratic effect of $\mathrm{pDMI}(\mathrm{pDMI} \times \mathrm{pDMI})$, and Trt by quadratic effect of $\mathrm{pDMI}($ Trt $\times \mathrm{pDMI} \times \mathrm{pDMI})$.

${ }^{2}$ Nonsignificant, with $P>0.20$; term was removed from the statistical model.

${ }^{3} \mathrm{NANMN}=$ nonammonia, nonmicrobial nitrogen.

${ }^{4} \mathrm{TRDOM}=$ true ruminally digested OM.

$=0.05)$ compared with the LC diet (Table 11). The difference in ruminal passage rate of pdNDF between $\mathrm{EC}$ and LC tended to be greatest for cows in the middle of the pDMI range (interaction $P=0.11$, quadratic; Figure $3 \mathrm{~A}$ ), and the reason for this is not known. These rates affected fiber digestion such that EC had greater pdNDF ruminal digestion ( $4.38 \mathrm{vs} .3 .48 \mathrm{~kg} / \mathrm{d}, P=0.01$ ) and digestibility (88.6 vs. $76.0 \%, P=0.03$ ) and lower pdNDF flux to the duodenum $(0.55$ vs. $1.10 \mathrm{~kg} / \mathrm{d}, P=$ 0.03 ) than LC (Table 9 ). The patterns for treatment by pDMI interactions for pdNDF ruminal digestibility (interaction $P=0.10$, quadratic; Figure $3 \mathrm{~B}$ ) and pdNDF flux (interaction $P=0.08$, quadratic; Figure $3 \mathrm{C}$ ) corresponded to pdNDF ruminal passage rate, such that the faster rate of pdNDF passage yielded lower pdNDF digestibility in the rumen and higher pdNDF flux from the rumen and vice versa. Despite differences in ruminal pdNDF digestion, no difference was observed in total-tract digestibility of pdNDF between treatments. Similar to pdNDF, EC had greater true ruminal digestibility of OM (68.3 vs. $61.4 \%, P=0.02)$ than $\mathrm{LC}$, and the difference was greater for cows in the middle of the pDMI range (interaction $P=0.05$, quadratic), but EC decreased total-tract OM digestibility (63.3 vs. $67.2 \%$,
$P=0.05)$ compared with LC (Table 10). The EC diet decreased DM total-tract digestibility (62.2 vs. $66.5 \%$, $P=0.04$ ) compared with the LC diet (Table 10), which is because of differences in $\mathrm{N}$ total-tract digestibility (Table 8).

As expected, ruminal turnover rate of NDF (4.47 vs. $3.57 \% / \mathrm{h}, P<0.001)$ was greater for EC than LC due to faster rates of passage of iNDF and digestion of pdNDF and despite slower passage of pdNDF (Table 11). Although rate of particle size reduction was not directly measured in this experiment, the faster passage rate of pdNDF observed for $\mathrm{LC}$ could be the result of greater fragility and breakdown of the more mature grass. Additionally, greater chewing time for LC may be responsible for greater breakdown of particles, resulting in faster passage rate of pdNDF because EC decreased eating time (42.1 vs. $50.8 \mathrm{~min} / \mathrm{kg}$ of forage NDF, $P=$ 0.03 ), ruminating time (88.6 vs. $101 \mathrm{~min} / \mathrm{kg}$ of forage NDF, $P=0.003$ ), and thus total chewing time (132 vs. $150 \mathrm{~min} / \mathrm{kg}$ of forage NDF, $P<0.001$ ) per unit of forage NDF intake compared with LC (Table 13). No difference in eating time per day $(P=0.31)$ was observed for EC and LC, but EC decreased ruminating time per day (523 vs. $562 \mathrm{~min} / \mathrm{d}, P=0.04$ ) compared with LC 
Table 9. Neutral detergent fiber digestion of cows fed treatment diets containing either early-cut or late-cut orchardgrass silage as the sole source of forage

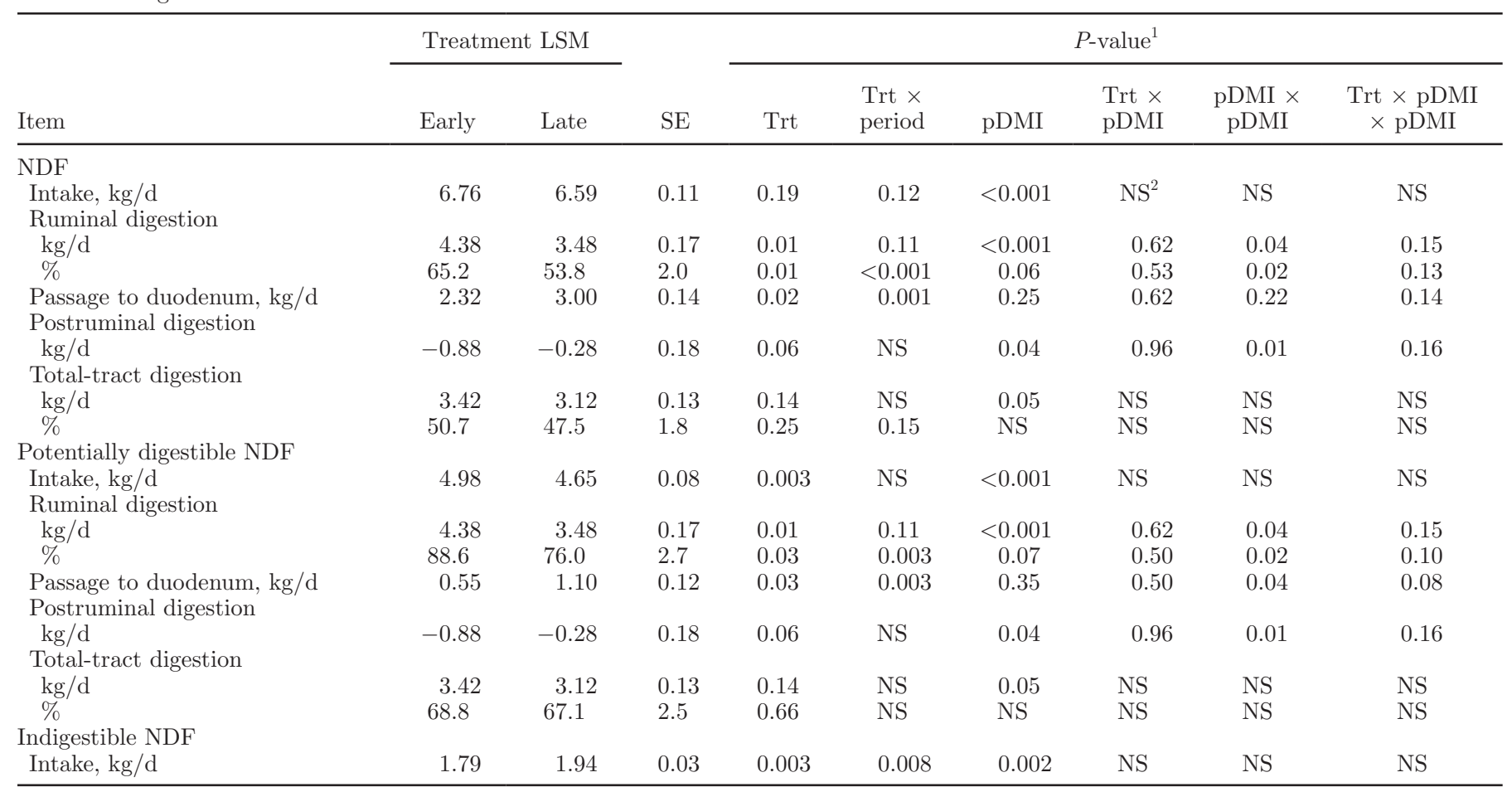

${ }^{1} P$-values for treatment (Trt), Trt by period interaction $($ Trt $\times$ period), preliminary DMI $(\mathrm{pDMI})$, Trt by pDMI interaction $($ Trt $\times$ pDMI), quadratic effect of $\mathrm{pDMI}(\mathrm{pDMI} \times \mathrm{pDMI})$, and Trt by quadratic effect of $\mathrm{pDMI}($ Trt $\times \mathrm{pDMI} \times \mathrm{pDMI})$.

${ }^{2}$ Nonsignificant, with $P>0.20$; term was removed from the statistical model.

Table 10. Dry matter and OM digestion of cows fed treatment diets containing either early-cut or late-cut orchardgrass silage as the sole source of forage

\begin{tabular}{|c|c|c|c|c|c|c|c|c|c|}
\hline Item & \multicolumn{2}{|c|}{ Treatment LSM } & $\mathrm{SE}$ & \multicolumn{6}{|c|}{$P$-value ${ }^{1}$} \\
\hline \multicolumn{10}{|l|}{$\mathrm{DM}$} \\
\hline Intake, $\mathrm{kg} / \mathrm{d}$ & 22.5 & 22.4 & 0.4 & 0.71 & 0.12 & 0.002 & $\mathrm{NS}^{2}$ & NS & NS \\
\hline \multicolumn{10}{|l|}{ Apparent total-tract digestion } \\
\hline $\mathrm{kg} / \mathrm{d}$ & 14.0 & 14.9 & 0.4 & 0.09 & NS & 0.009 & NS & NS & NS \\
\hline Intake, $\mathrm{kg} / \mathrm{d}$ & 20.5 & 20.6 & 0.4 & 0.77 & 0.11 & 0.002 & NS & NS & NS \\
\hline \multicolumn{10}{|l|}{ Apparent ruminal digestion } \\
\hline $\mathrm{kg} / \mathrm{d}$ & 9.91 & 8.78 & 0.51 & 0.19 & 0.04 & 0.01 & 0.21 & 0.33 & 0.10 \\
\hline$\%$ & 48.9 & 43.4 & 2.0 & 0.15 & $<0.001$ & 0.65 & 0.22 & 0.46 & 0.09 \\
\hline \multicolumn{10}{|l|}{ True ruminal digestion } \\
\hline $\mathrm{kg} / \mathrm{d}$ & 13.7 & 12.3 & 0.5 & 0.08 & NS & 0.006 & 0.29 & 0.26 & 0.14 \\
\hline$\%$ & 68.3 & 61.4 & 1.5 & 0.02 & $<0.001$ & 0.47 & 0.19 & 0.61 & 0.05 \\
\hline $\mathrm{kg} / \mathrm{d}$ & 12.9 & 13.8 & 0.3 & 0.05 & NS & 0.01 & NS & NS & NS \\
\hline$\%$ & 63.3 & 67.2 & 1.1 & 0.05 & 0.03 & NS & NS & NS & NS \\
\hline
\end{tabular}

${ }^{1} P$-values for treatment $($ Trt), Trt by period interaction $($ Trt $\times$ period), preliminary DMI $(\mathrm{pDMI})$, Trt by pDMI interaction $($ Trt $\times$ pDMI), quadratic effect of $\mathrm{pDMI}(\mathrm{pDMI} \times \mathrm{pDMI})$, and Trt by quadratic effect of $\mathrm{pDMI}($ Trt $\times \mathrm{pDMI} \times \mathrm{pDMI})$.

${ }^{2}$ Nonsignificant, with $P>0.20$; term was removed from the statistical model. 
Table 11. Rumen kinetics of cows fed treatment diets containing either early-cut or late-cut orchardgrass silage as the sole source of forage

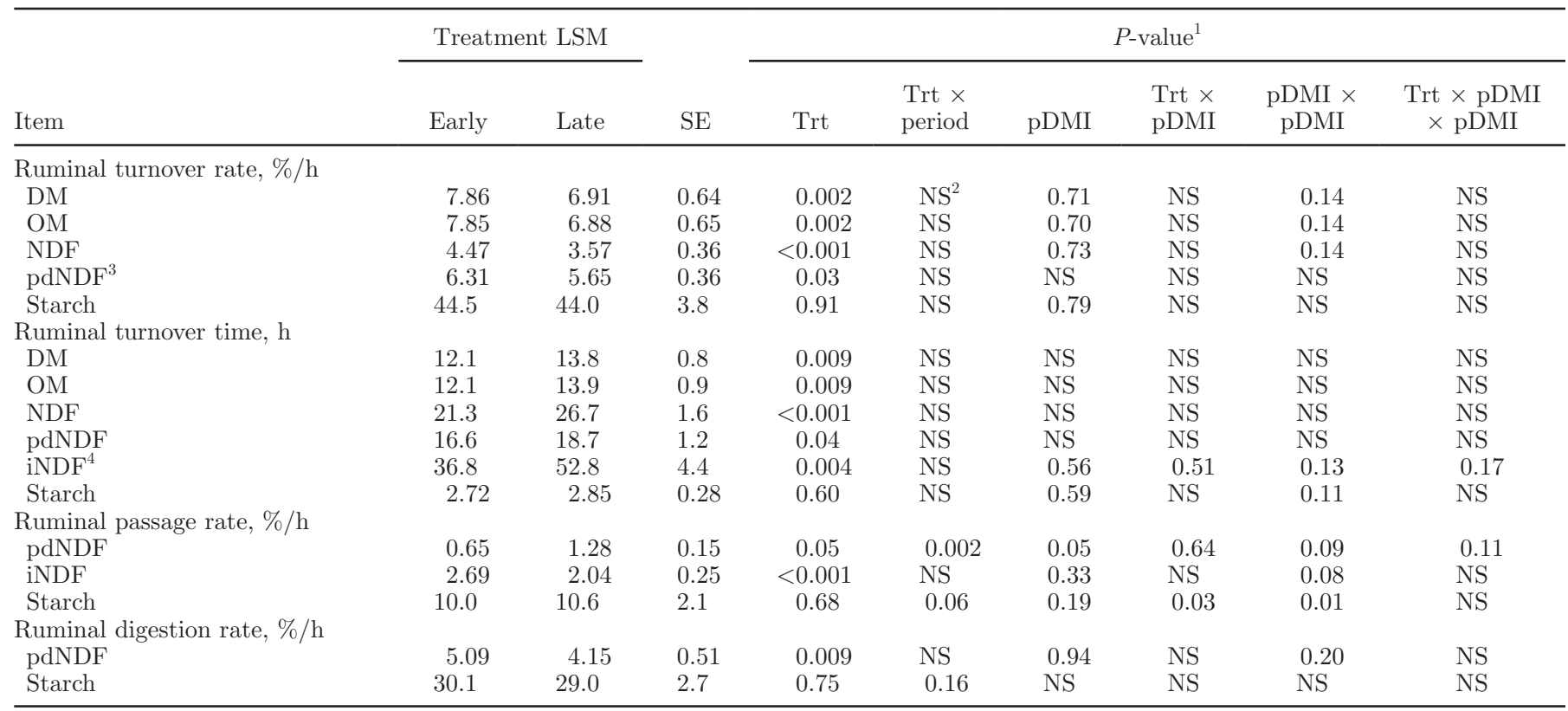

${ }^{1} P$-values for treatment $($ Trt $)$, Trt by period interaction $($ Trt $\times$ period), preliminary DMI $(\mathrm{pDMI})$, Trt by pDMI interaction $($ Trt $\times$ pDMI), quadratic effect of $\mathrm{pDMI}(\mathrm{pDMI} \times \mathrm{pDMI})$, and Trt by quadratic effect of $\mathrm{pDMI}($ Trt $\times \mathrm{pDMI} \times \mathrm{pDMI})$.

${ }^{2}$ Nonsignificant, with $P>0.20$; term was removed from the statistical model.

${ }^{3} \mathrm{pdNDF}=$ potentially digestible NDF.

${ }^{4} \mathrm{iNDF}=$ indigestible NDF.

(Table 13). The lower ruminating time observed for EC may be because of the smaller rumen pool size (Table 12) for EC compared with LC.

Grass maturity and its interaction with pDMI did not affect ruminal $\mathrm{pH}$ (Table 6) despite lower starch intake for EC compared with LC (Table 5). This is likely because EC tended to increase OM truly digested in the rumen (13.7 vs. $12.3 \mathrm{~kg} / \mathrm{d}, P=0.08$; Table 10$)$ compared with LC and because increased salivary buffer secretion through greater chewing time for LC (Table 13) may have offset the expected reduction in $\mathrm{pH}$ because of greater starch intake for LC (Table 5).

We were unable to detect a treatment by pDMI interaction for DMI, rumen pools, or chewing activity. We expected to detect an interaction between treatment and pDMI because ruminal distention becomes

Table 12. Rumen pools of cows fed treatment diets containing either early-cut or late-cut orchardgrass silage as the sole source of forage

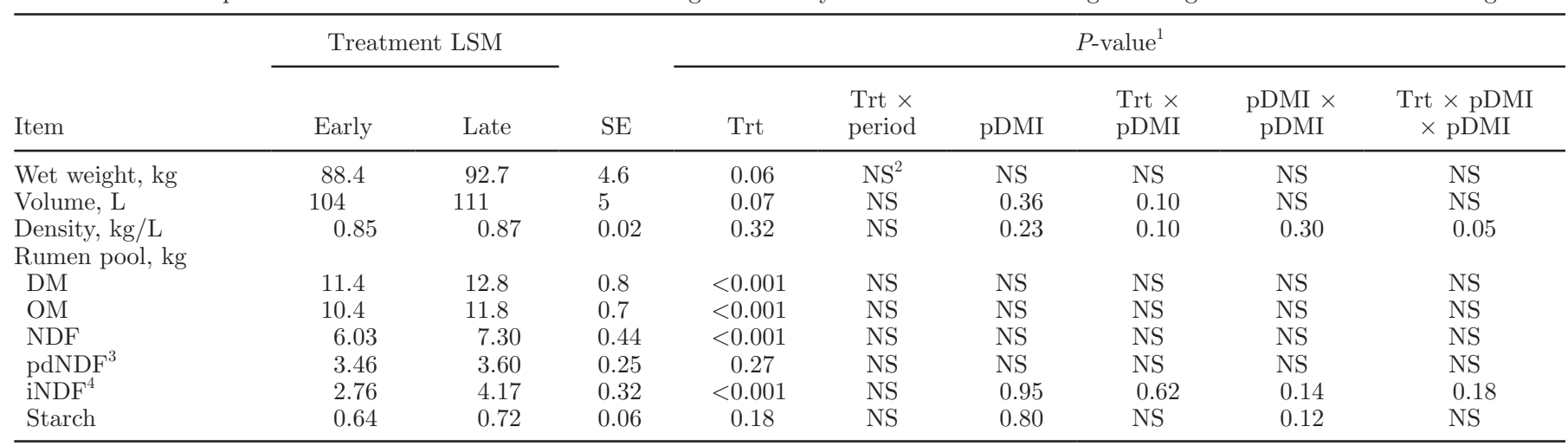

${ }^{1} P$-values for treatment (Trt), Trt by period interaction (Trt $\times$ period), preliminary DMI $(\mathrm{pDMI})$, Trt by pDMI interaction $($ Trt $\times$ pDMI), quadratic effect of $\mathrm{pDMI}(\mathrm{pDMI} \times \mathrm{pDMI})$, and Trt by quadratic effect of $\mathrm{pDMI}($ Trt $\times \mathrm{pDMI} \times \mathrm{pDMI})$.

${ }^{2}$ Nonsignificant, with $P>0.20$; term was removed from the statistical model.

${ }^{3}$ pdNDF $=$ potentially digestible NDF.

${ }^{4} \mathrm{iNDF}=$ indigestible NDF 


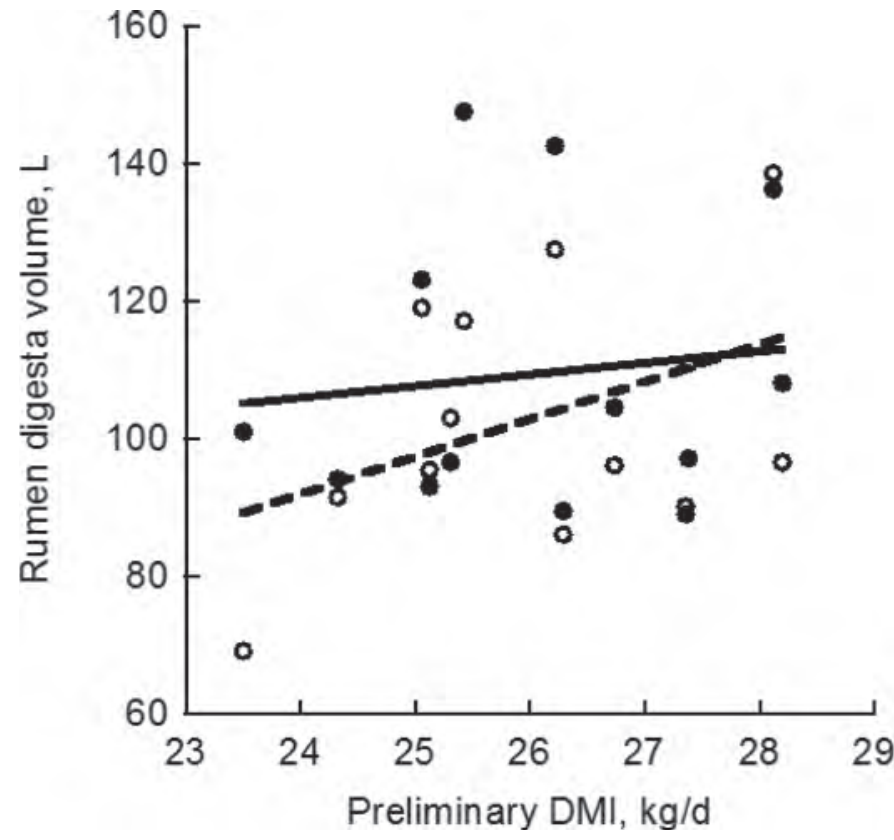

Figure 2. Interaction of early (open circles, dashed line) and late (closed circles, solid line) orchardgrass maturity with preliminary DMI for rumen digesta volume $(P=0.10$, linear). Raw data were adjusted for period effects. The preliminary DMI on the $\mathrm{x}$-axis are the mean DMI of individual cows during the final $4 \mathrm{~d}$ of the preliminary period when all cows were fed a common diet. The best-fit lines are drawn to demonstrate the significant interaction even if the individual relationships are not significant.

a greater constraint on feed intake as feed intake and milk yield increases (Oba and Allen, 1999; Voelker et al., 2002). Because treatment did not affect or interact with pDMI to affect feed intake, the dominant mechanism controlling DMI in this experiment is not clear. Metabolites or hormones (not measured), or both, might have provided additional clues to determine what limited intake.

\section{Effects of pDMI on Ruminal Passage Rates}

Experimental data on rates of passage from the rumen, particularly for individual feed fractions, are scarce. Given the impact of passage on ruminal digestion and microbial growth, quantitative knowledge of rates of nutrient passage from the rumen is needed to better understand nutrient availability in ruminants and improve nutrition models. Furthermore, because passage rates from the rumen generally increase with increased intake, measurements of ruminal passage rates of nutrients over a wide range of DMI are necessary. We measured the effects of DMI on rates of passage of nutrients from the rumen using the pool and flux method (Robinson et al., 1987).
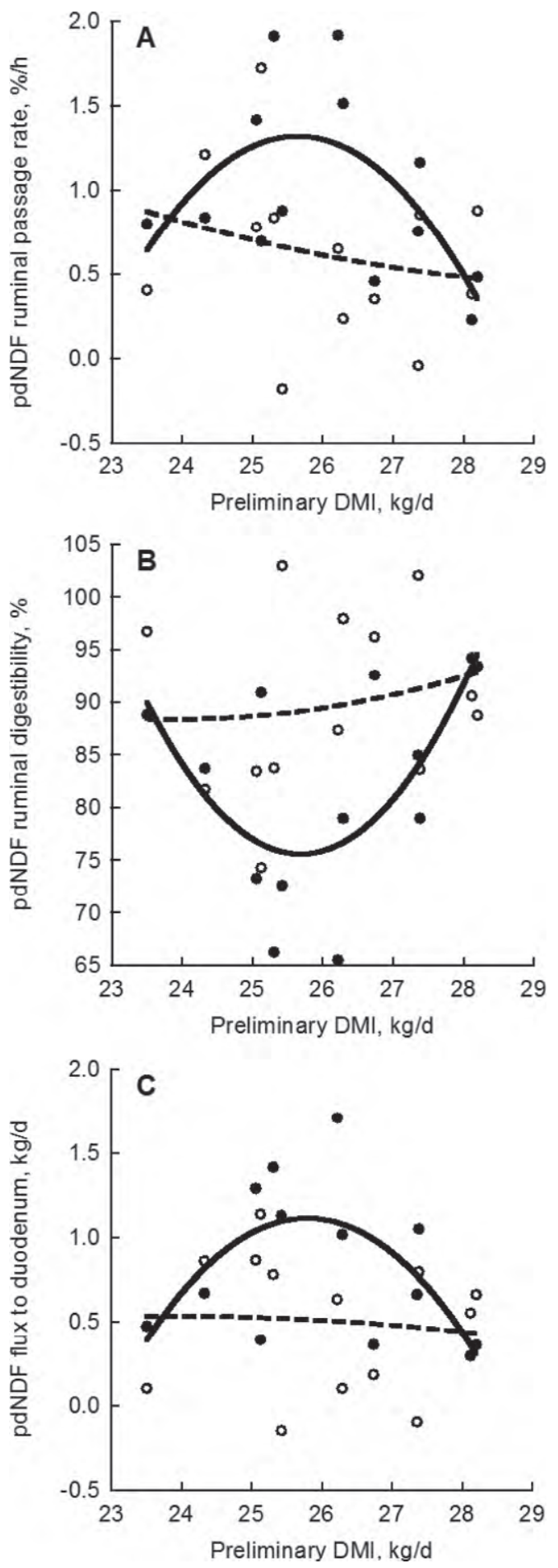

Figure 3. Interaction of early (open circles, dashed line) and late (closed circles, solid line) orchardgrass maturity with preliminary DMI for potentially digestible NDF (pdNDF) (A) ruminal passage rate $(P$ $=0.11$, quadratic $)$, $(\mathrm{B})$ ruminal digestibility $(P=0.10$, quadratic $)$, and $(\mathrm{C})$ flux to the duodenum $(P=0.08$, quadratic). Raw data were adjusted for period and treatment $\times$ period effects. The preliminary DMI on the $\mathrm{x}$-axis are the mean DMI of individual cows during the final $4 \mathrm{~d}$ of the preliminary period when all cows were fed a common diet. The best-fit lines are drawn to demonstrate the significant interaction even if the individual relationships are not significant. 
Rate of ruminal passage for starch was related to level of intake. As pDMI increased, EC slightly decreased ruminal passage rate of starch and $\mathrm{LC}$ increased it (interaction $P=0.03$; Figure $4 \mathrm{~A}$ ). This is consistent with expected effects of passage rate on true rumen digestibility of starch; EC slightly increased true ruminal starch digestibility and LC decreased it as pDMI increased (interaction $P=0.15$; Figure $4 \mathrm{~B}$ ). The reverse was observed for postruminal starch digestibility (interaction $P=0.11$; Figure $4 \mathrm{C}$ ).

Fiber passage rates were also related to level of intake. Rate of ruminal passage for pdNDF tended to be related to $\mathrm{pDMI}$ (interaction $P=0.11$, quadratic) and influenced pdNDF ruminal digestion as previously discussed (Figure 3). Rate of ruminal passage of iNDF tended to be quadratically related to pDMI $(P$ $=0.08$, quadratic; Figure 5), independent of treatment response. Although we expected iNDF passage rate to increase as pDMI increased, we observed that cows with low pDMI had faster iNDF passage rates than cows in the middle of the pDMI range. The reason for this is unclear.

\section{Effects of Treatment and pDMI on N Flux and Microbial Efficiency}

Flux of NANMN passed from the rumen to the duodenum was related to pDMI and the response differed by treatment; EC increased NANMN flux and LC decreased it as pDMI increased (interaction $P=$ 0.04; Figure 6 ). This interaction contributed to a treatment by pDMI interaction for NAN flux (interaction $P=0.08$; Table 8), as level of intake did not affect MN flux. In a review by Clark et al. (1992), positive linear relationships between $\mathrm{OM}$ intake and fluxes of NAN, NANMN, and MN were reported as OM intake increased over a very wide range $(3$ to $23 \mathrm{~kg} / \mathrm{d}$ ). The higher DMI and narrower range of DMI in the present

Table 13. Chewing activity of cows fed treatment diets containing either early-cut or late-cut orchardgrass silage as the sole source of forage

\begin{tabular}{|c|c|c|c|c|c|c|c|c|c|}
\hline \multirow[b]{2}{*}{ Item } & \multicolumn{2}{|c|}{ Treatment LSM } & \multirow[b]{2}{*}{$\mathrm{SE}$} & \multicolumn{6}{|c|}{$P$-value ${ }^{1}$} \\
\hline & Early & Late & & Trt & $\begin{array}{l}\text { Trt } \times \\
\text { period }\end{array}$ & pDMI & $\begin{array}{l}\text { Trt } \times \\
\text { pDMI }\end{array}$ & $\begin{array}{c}\mathrm{pDMI} \times \\
\mathrm{pDMI}\end{array}$ & $\begin{array}{c}\text { Trt } \times \mathrm{pDMI} \\
\quad \times \mathrm{pDMI}\end{array}$ \\
\hline \multicolumn{10}{|l|}{ Meals } \\
\hline Bouts/d & 9.07 & 8.75 & 0.42 & 0.64 & 0.03 & $\mathrm{NS}^{2}$ & NS & NS & NS \\
\hline Length, $\min /$ bout & 28.9 & 31.4 & 1.5 & 0.28 & 0.009 & NS & NS & NS & NS \\
\hline Interval, min & 143 & 150 & 8 & 0.58 & 0.11 & NS & NS & NS & NS \\
\hline \multicolumn{10}{|l|}{ Meal size, kg } \\
\hline $\mathrm{DM}$ & 2.57 & 2.60 & 0.13 & 0.87 & NS & 0.05 & NS & NS & NS \\
\hline $\mathrm{OM}$ & 2.33 & 2.39 & 0.12 & 0.73 & NS & 0.05 & NS & NS & NS \\
\hline NDF & 0.77 & 0.77 & 0.04 & 0.98 & NS & 0.05 & NS & NS & NS \\
\hline $\operatorname{pdNDF}^{3}$ & 0.57 & 0.54 & 0.03 & 0.57 & 0.11 & 0.05 & NS & NS & NS \\
\hline $\mathrm{iNDF}^{4}$ & 0.20 & 0.23 & 0.01 & 0.20 & NS & 0.06 & NS & NS & NS \\
\hline Starch & 0.66 & 0.73 & 0.04 & 0.14 & NS & 0.07 & NS & NS & NS \\
\hline \multicolumn{10}{|l|}{ Eating time } \\
\hline $\operatorname{Min} / \mathrm{d}$ & 255 & 268 & 12 & 0.31 & NS & NS & NS & NS & NS \\
\hline Min/kg of DMI & 11.0 & 12.7 & 1.0 & 0.08 & NS & 0.21 & 0.88 & 0.92 & 0.14 \\
\hline Min/kg of NDF intake & 36.4 & 43.0 & 3.2 & 0.05 & NS & 0.18 & 0.89 & 0.93 & 0.13 \\
\hline Min $/ \mathrm{kg}$ of forage NDF intake & 42.1 & 50.8 & 3.9 & 0.03 & NS & 0.20 & 0.93 & 0.89 & 0.14 \\
\hline \multicolumn{10}{|l|}{ Rumination } \\
\hline Bouts/d & 14.9 & 15.3 & 0.7 & 0.56 & NS & 0.57 & 0.08 & 0.32 & 0.04 \\
\hline Length, min/bout & 35.4 & 36.4 & 2.2 & 0.58 & NS & 0.16 & 0.02 & 0.26 & 0.13 \\
\hline Interval, min & 57.3 & 50.2 & 2.1 & 0.04 & 0.14 & NS & NS & NS & NS \\
\hline \multicolumn{10}{|l|}{ Ruminating time } \\
\hline $\operatorname{Min} / \mathrm{d}$ & 523 & 562 & 16 & 0.04 & NS & 0.18 & NS & NS & NS \\
\hline Min/kg of DMI & 23.1 & 25.2 & 0.8 & 0.02 & NS & NS & NS & NS & NS \\
\hline Min/kg of NDF intake & 77.2 & 85.7 & 2.7 & 0.01 & NS & NS & NS & NS & NS \\
\hline Min/ $/ \mathrm{kg}$ of forage NDF intake & 88.6 & 101.1 & 3.1 & 0.003 & NS & NS & NS & NS & NS \\
\hline \multicolumn{10}{|l|}{ Total chewing time } \\
\hline $\operatorname{Min} / \mathrm{d}$ & 778 & 830 & 19 & 0.006 & NS & NS & NS & NS & NS \\
\hline Min/kg of DMI & 34.5 & 37.4 & 1.1 & 0.006 & NS & 0.18 & NS & NS & NS \\
\hline Min/kg of NDF intake & 115 & 127 & 4 & 0.003 & NS & 0.15 & NS & NS & NS \\
\hline Min $/ \mathrm{kg}$ of forage NDF intake & 132 & 150 & 4 & $<0.001$ & NS & 0.17 & NS & NS & NS \\
\hline
\end{tabular}

${ }^{1} P$-values for treatment $($ Trt $)$, Trt by period interaction $($ Trt $\times$ period), preliminary DMI $(\mathrm{pDMI})$, Trt by pDMI interaction $($ Trt $\times$ pDMI), quadratic effect of pDMI $(\mathrm{pDMI} \times \mathrm{pDMI})$, and Trt by quadratic effect of $\mathrm{pDMI}($ Trt $\times \mathrm{pDMI} \times \mathrm{pDMI})$.

${ }^{2}$ Nonsignificant, with $P>0.20$; term was removed from the statistical model.

${ }^{3}$ pdNDF $=$ potentially digestible NDF.

${ }^{4} \mathrm{iNDF}=$ indigestible $\mathrm{NDF}$. 

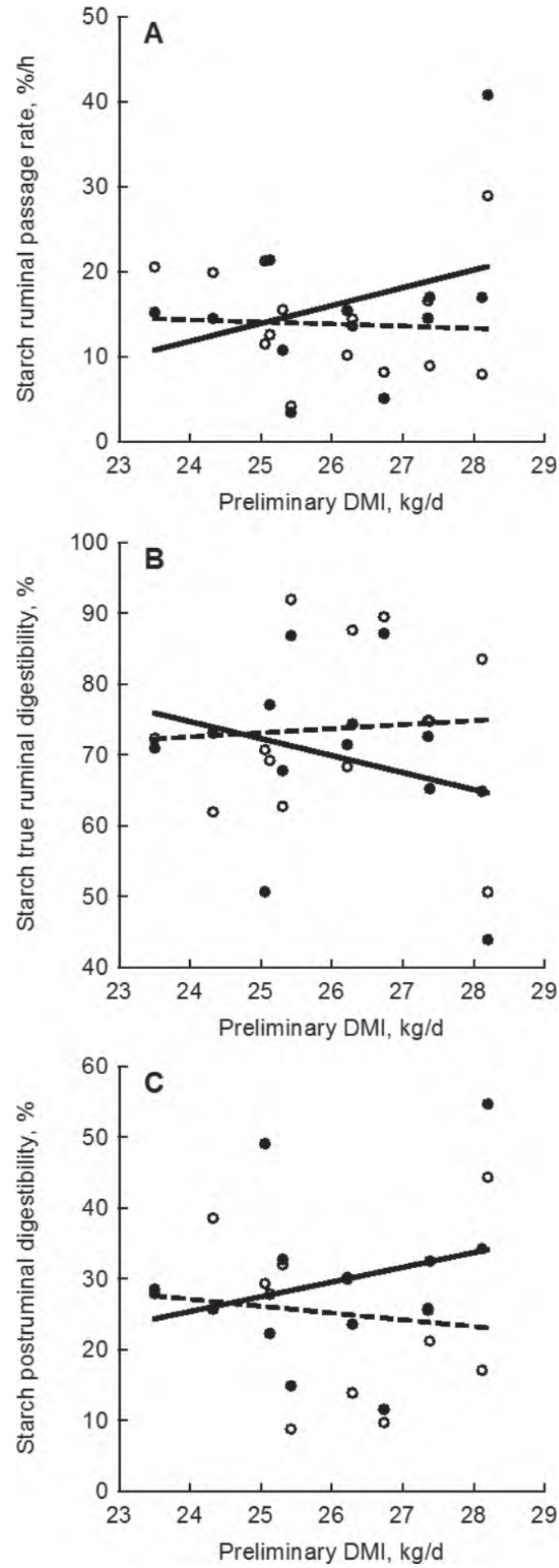

Figure 4. Interaction of early (open circles, dashed line) and late (closed circles, solid line) orchardgrass maturity with preliminary DMI for starch (A) ruminal passage rate $(P=0.03$, linear $),(B)$ true ruminal digestibility $(P=0.15$, linear $)$, and $(\mathrm{C})$ postruminal digestibility $(P=0.11$, linear $)$. Raw data were adjusted for period and treatment $x$ period effects. The preliminary DMI on the $\mathrm{x}$-axis are the mean DMI of individual cows during the final $4 \mathrm{~d}$ of the preliminary period when all cows were fed a common diet. The best-fit lines are drawn to demonstrate the significant interaction even if the individual relationships are not significant.

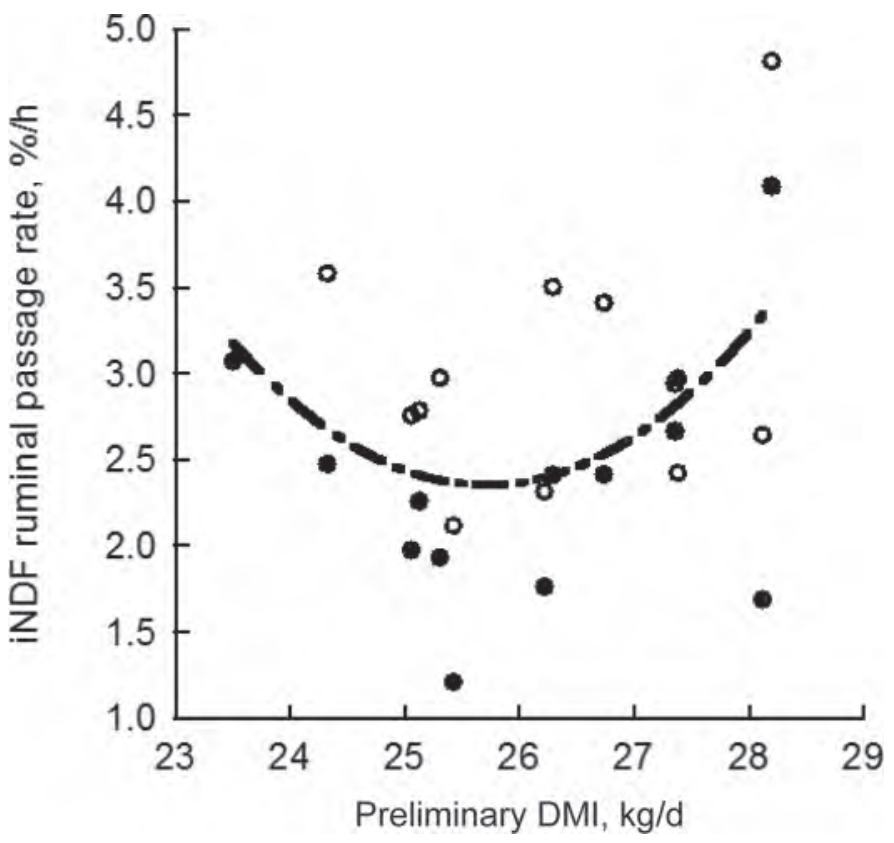

Figure 5. Relationship of early (open circles) and late (closed circles) orchardgrass maturity with preliminary DMI for indigestible NDF (iNDF) ruminal passage rate $(P=0.08$, quadratic). Raw data were adjusted for period effects. The preliminary DMI on the $\mathrm{x}$-axis are the mean DMI of individual cows during the final $4 \mathrm{~d}$ of the preliminary period when all cows were fed a common diet.

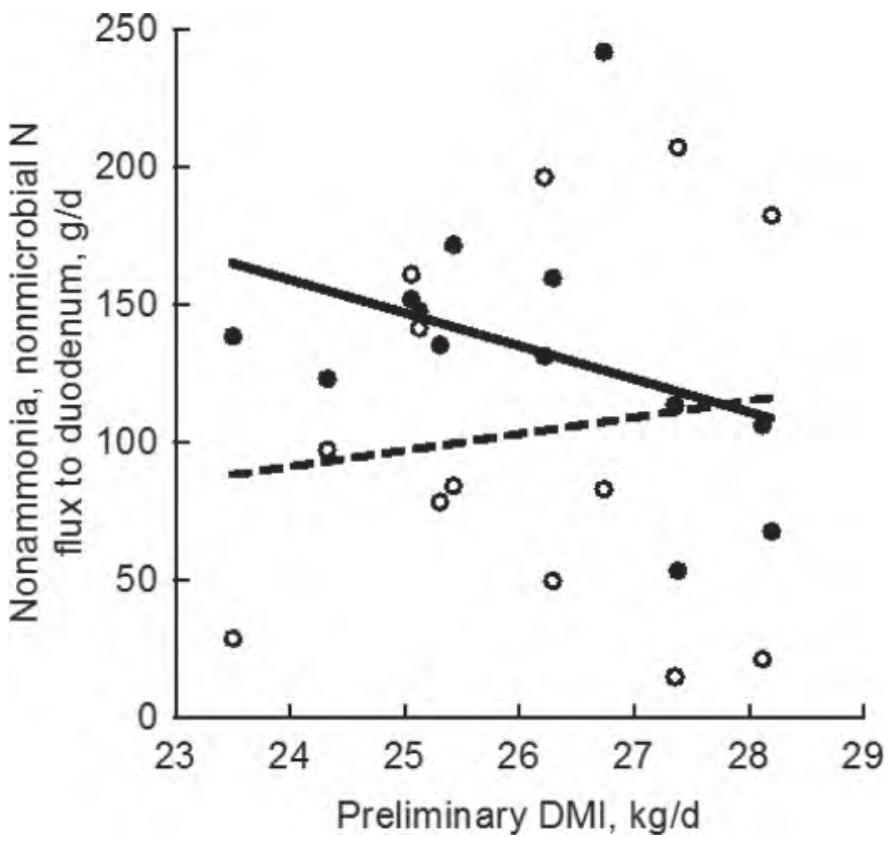

Figure 6. Interaction of early (open circles, dashed line) and late (closed circles, solid line) orchardgrass maturity with preliminary DMI for nonammonia, nonmicrobial $\mathrm{N}$ flux to the duodenum $(P=0.04$, linear). Raw data were adjusted for period and treatment $\times$ period effects. The preliminary DMI on the $\mathrm{x}$-axis are the mean DMI of individual cows during the final $4 \mathrm{~d}$ of the preliminary period when all cows were fed a common diet. The best-fit lines are drawn to demonstrate the significant interaction even if the individual relationships are not significant. 


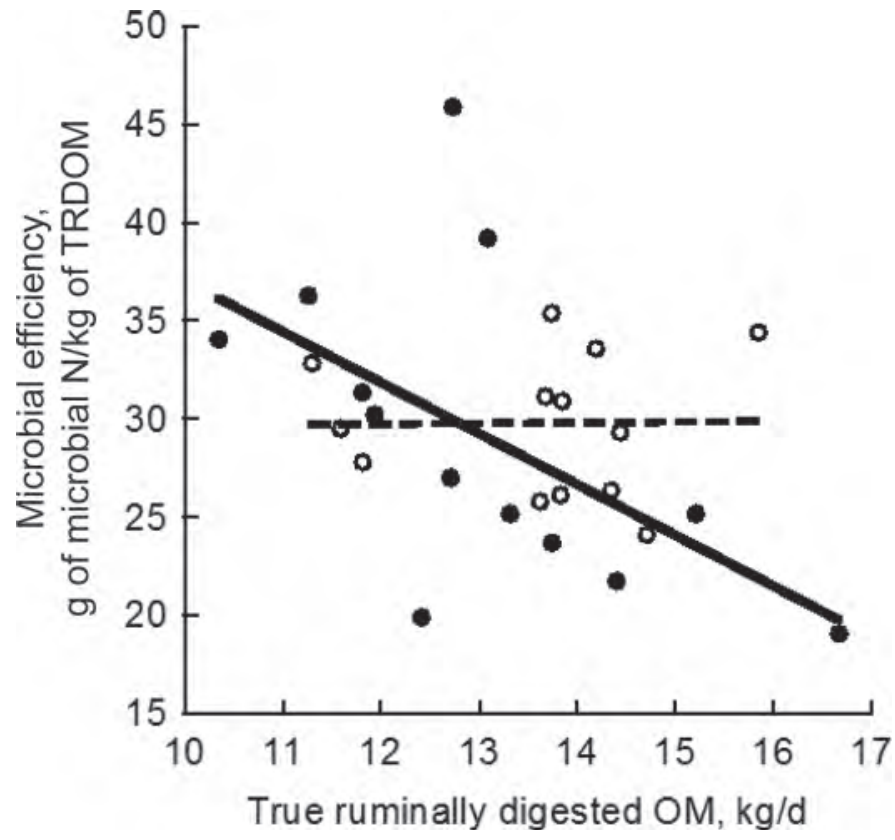

Figure 7. Relationship between true ruminally digested OM (TRDOM) and microbial efficiency for early (open circles, dashed line; $P=0.97, \mathrm{R}^{2}<0.001$ ) and late (closed circles, solid line; microbial efficiency, $\mathrm{g}$ of microbial $\mathrm{N} / \mathrm{kg}$ of TRDOM $=62.9-2.59 \times$ TRDOM, $\mathrm{kg} / \mathrm{d} ; P=0.05, \mathrm{R}^{2}=0.30$ ) orchardgrass maturity.

experiment might have precluded detection of the positive relationships demonstrated by Clark et al. (1992).

Based on studies with continuous-culture fermenters, increases in solid and liquid dilution rates, which can be associated with increased intake, resulted in greater microbial efficiency (Crawford et al., 1980; Shriver et al., 1986). In the current experiment, microbial efficiency was not related to pDMI $(P \geq 0.29$; Table 8$)$ despite the linear increase in true ruminally digested $\mathrm{OM}$ with increasing pDMI $(P=0.006$; Table 10$)$. No relationship existed between microbial efficiency and true ruminally digested $\mathrm{OM}$ for cows consuming $\mathrm{EC}\left(P=0.97, \mathrm{R}^{2}<\right.$ 0.001); however, microbial efficiency of cows consuming LC decreased dramatically as true ruminally digested OM increased $\left(P=0.05, \mathrm{R}^{2}=0.30\right.$; Figure 7$)$, indicating that factors other than availability of energy limited efficiency of MN production and energy from OM fermentation was uncoupled from microbial growth (Russell and Cook, 1995). Similarly, Oba and Allen (2003b) reported that efficiency of MN production was inversely related to true ruminally digested $\mathrm{OM}(\mathrm{kg} / \mathrm{d})$ in an experiment comparing starch concentration and fermentability of diets in dairy cattle.

\section{CONCLUSIONS}

Increased grass maturity decreased ruminal NDF digestibility and ruminal turnover of NDF and DM, increasing rumen pools of NDF and DM, but did not affect or interact with pDMI to affect feed intake. This suggested that the control of feed intake was dominated by mechanism(s) other than ruminal distention in this experiment. Adjusting rations based on mature grass with concentrates to similar concentrations of forage NDF might have opposite effects on yield of milk and concentration of milk fat, minimizing treatment effects on FCM.

\section{ACKNOWLEDGMENTS}

This project was supported by National Research Initiative Competitive Grant no. 2006-35206-16708 from the USDA National Institute of Food and Agriculture (Washington, DC). The authors thank N. K. Ames (Department of Large Animal Clinical Science, College of Veterinary Medicine, Michigan State University, East Lansing) for performing duodenal and ruminal cannulation surgeries; D. G. Main, R. A. Longuski, and Y. Ying (Department of Animal Science, Michigan State University) and R. E. Kreft and the staff of the Michigan State University Dairy Cattle Teaching and Research Center for their technical assistance and support; Barenbrug USA (Tangent, OR) for their donation of Baridana orchardgrass seed; and West Central Soy Cooperative (Ralston, IA) for donating the SoyPLUS protein supplement.

\section{REFERENCES}

Allen, M. S. 1996. Physical constraints on voluntary intake of forages by ruminants. J. Anim. Sci. 74:3063-3075.

Broderick, G. A., and J. H. Kang. 1980. Automated simultaneous determination of ammonia and total amino acids in rumen fluid and in vitro media. J. Dairy Sci. 63:64-75.

Chouinard, P. Y., L. Corneau, D. M. Barbano, L. E. Metzger, and D. E. Bauman. 1999. Conjugated linoleic acids alter milk fatty acid composition and inhibit milk fat secretion in dairy cows. J. Nutr. 129:1579-1584.

Christie, W. W. 1982. A simple procedure for rapid transmethylation of glycerolipids and cholesteryl esters. J. Lipid Res. 23:1072-1075.

Clark, J. H., T. H. Klusmeyer, and M. R. Cameron. 1992. Microbial protein synthesis and flows of nitrogen fractions to the duodenum of dairy cows. J. Dairy Sci. 75:2304-2323.

Cochran, R. C., D. C. Adams, J. D. Wallace, and M. L. Galyean. 1986. Predicting digestibility of different diets with internal markers: Evaluation of four potential markers. J. Anim. Sci. 63:1476-1483.

Cook, R. D., and S. Weisberg. 1982. Residuals and influence in regression. Chapman and Hall, New York, NY.

Crawford, R. J. Jr., W. H. Hoover, and L. L. Junkins. 1980. Effects of solids and liquid flows on fermentation in continuous cultures. II. Nitrogen partitioning and efficiency of microbial synthesis. J. Anim. Sci. 51:986-995.

Dado, R. G., and M. S. Allen. 1994. Variation in and relationships among feeding, chewing, and drinking variables for lactating dairy cows. J. Dairy Sci. 77:132-144.

Goering, H. K., and P. J. Van Soest. 1970. Forage Fiber Analysis (Apparatus, Reagents, Procedures, and Some Applications). Agric. Handbook No. 379. Agricultural Research Service-US Department of Agriculture (ARS-USDA), Washington, DC. 
Hach, C. C., B. K. Bowden, A. B. Kopelove, and S. V. Brayton. 1987. More powerful peroxide Kjeldahl digestion method. J. Assoc. Off. Anal. Chem. 70:783-787.

Hara, A., and N. S. Radin. 1978. Lipid extraction of tissues with a low-toxicity solvent. Anal. Biochem. 90:420-426.

Joy, M. T., E. J. DePeters, J. G. Fadel, and R. A. Zinn. 1997. Effects of corn processing on the site and extent of digestion in lactating cows. J. Dairy Sci. 80:2087-2097.

Jung, H. G., and M. S. Allen. 1995. Characteristics of plant cell walls affecting intake and digestibility of forages by ruminants. J. Anim. Sci. 73:2774-2790.

Karkalas, J. 1985. An improved enzymatic method for the determination of native and modified starch. J. Sci. Food Agric. 36:10191027.

Kramer, J. K., V. Fellner, M. E. Dugan, F. D. Sauer, M. M. Mossoba, and M. P. Yurawecz. 1997. Evaluating acid and base catalysts in the methylation of milk and rumen fatty acids with special emphasis on conjugated dienes and total trans fatty acids. Lipids 32:1219-1228.

Lammers, B. P., D. R. Buckmaster, and A. J. Heinrichs. 1996. A simplified method for the analysis of particle sizes of forage and total mixed rations. J. Dairy Sci. 79:922-928.

Mertens, D. R. 2002. Gravimetric determination of amylase-treated neutral detergent fiber in feeds using refluxing in beakers or crucibles: Collaborative study. J. AOAC Int. 85:1217-1240.

NRC. 2001. Nutrient Requirements of Dairy Cattle. 7th rev. ed. Natl. Acad., Washington, DC.

Oba, M., and M. S. Allen. 1999. Effects of brown midrib 3 mutation in corn silage on dry matter intake and productivity of high yielding dairy cows. J. Dairy Sci. 82:135-142.

Oba, M., and M. S. Allen. 2003a. Effects of corn grain conservation method on feeding behavior and productivity of lactating dairy cows at two dietary starch concentrations. J. Dairy Sci. 86:174183.

Oba, M., and M. S. Allen. 2003b. Effects of diet fermentability on efficiency of microbial nitrogen production in lactating dairy cows. J. Dairy Sci. 86:195-207.
Poppi, D. P., D. J. Minson, and J. H. Ternouth. 1981. Studies of cattle and sheep eating leaf and stem fractions of grasses. III. The retention time in the rumen of large feed particles. Aust. J. Agric. Res. 32:123-137.

Robinson, P. J., S. Tamminga, and A. M. van Vuuren. 1987. Influence of declining level of feed intake and varying proportion of starch in the concentrate on rumen ingesta quantity, composition and kinetics of ingesta turnover in dairy cows. Livest. Prod. Sci. 17:37-62.

Russell, J. B., and G. M. Cook. 1995. Energetics of bacterial growth: Balance of anabolic and catabolic reactions. Microbiol. Rev. 59:48-62.

Shriver, B. J., W. H. Hoover, J. P. Sargent, R. J. Crawford Jr., and W. V. Thayne. 1986. Fermentation of a high concentrate diet as affected by ruminal $\mathrm{pH}$ and digesta flow. J. Dairy Sci. 69:413-419.

Smith, L. W., H. K. Goering, and C. H. Gordon. 1972. Relationships of forage compositions with rates of cell wall digestion and indigestibility of cell walls. J. Dairy Sci. 55:1140-1147.

Ulyatt, M. J. 1983. Plant fibre and regulation of digestion in the ruminant. Page 103 in Fibre in Human and Animal Nutrition. G. Wallace and L. Bell, ed. The Royal Soc. of New Zealand, Wellington, NZ.

Voelker, J. A., G. M. Burato, and M. S. Allen. 2002. Effect of pretrial milk yield on responses of feed intake, digestion, and production to dietary forage concentration. J. Dairy Sci. 85:2650-2661.

Voelker Linton, J. A., and M. S. Allen. 2008. Nutrient demand interacts with forage family to affect intake and digestion responses in dairy cows. J. Dairy Sci. 91:2694-2701.

Wildman, E. E., G. M. Jones, P. E. Wagner, R. L. Boman, H. F. Troutt Jr., and T. N. Lesch. 1982. A dairy cow body condition scoring system and its relationship to selected production characteristics. J. Dairy Sci. 65:495-501.

Zinn, R. A., and F. N. Owens. 1986. A rapid procedure for purine measurement and its use for estimating net ruminal protein synthesis. Can. J. Anim. Sci. 66:157-166. 